\title{
FREEZE INJURY
}

AND SUBSEQUENT SEASONAL CHANGES IN

VALENCIA ORANGES AND GRAPEFRUIT

E. T. BARTHOLOMEW

R. P. HORSPOOL

W. B. SINCLAIR

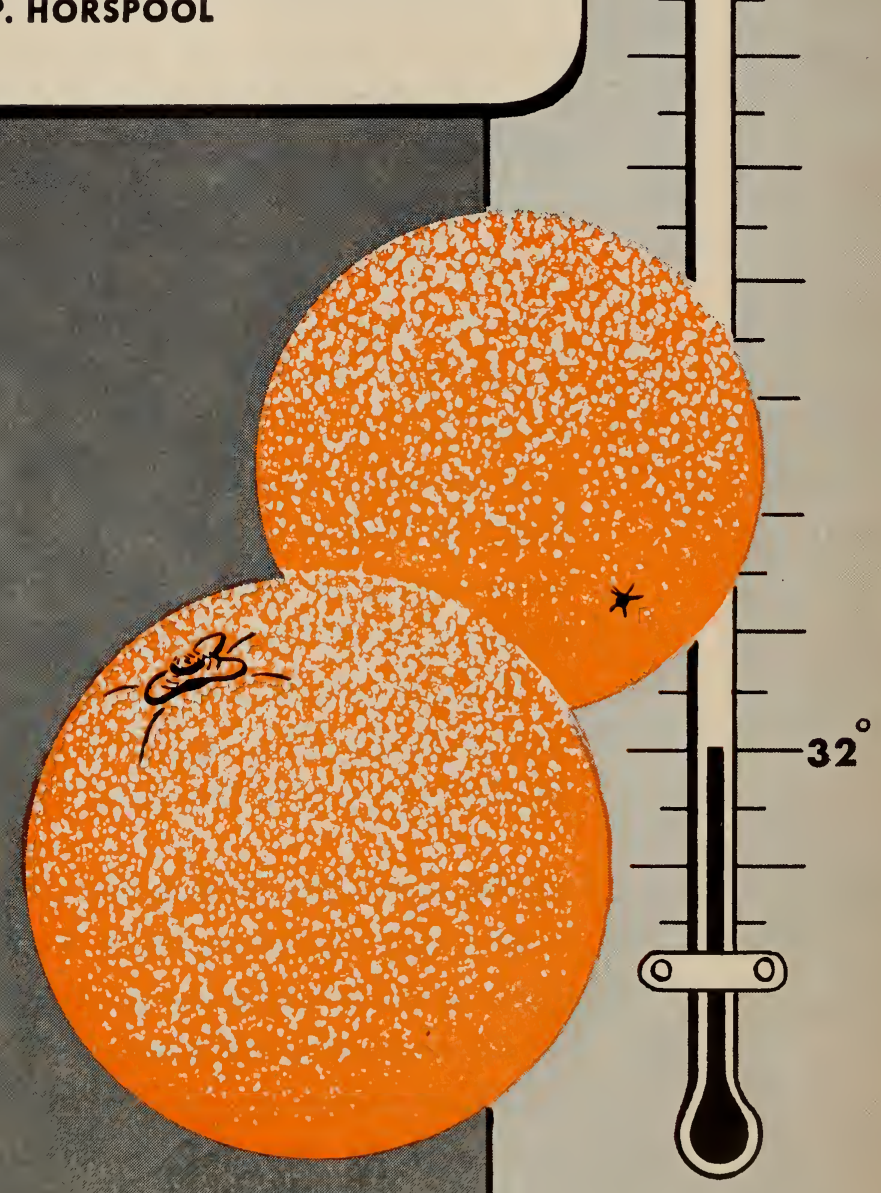

CALIORNIA ACRICULTURAL EXPERTMENT STATION

THE COLLCE OF ACRICULTURE

UNIVEREITY OF CAMTORNIA - BSRKALYY 


\section{The purpose of this study was to find out how citrus fruits}

were affected by the freezing temperatures of the winter 1948-1949.

THE CITRUS INDUSTRY WANTED TO KNOW the probable out-turn of frost-injured citrus fruits, the various stages of deterioration, and the recovery of fruits from various degrees of frost injury.

THIS PROBLEM IS IMPORTANT TO marketing agencies, shipping organizations, citrus products plants, and growers who are vitally interested in making an early estimate of crop damage. If such estimates can be fairly accurateneither overly optimistic nor too conservative-serious losses may be prevented.

\section{HOW THE PROBLEM WAS HANDLED:}

The studies were confined almost entirely to Valencia oranges, with a few similar tests being made on Marsh grapefruit. (Washington navels and lemons were studied following the 1913 freeze.)

Fruit samples taken from groves known to be badly frozen, and from others thought to be lightly frozen were investigated periodically. These samples were inspected for crystallization (hesperidin crystals), drying of cell walls, a milky or cloudy condition on cross cuts, and granulation. Following observation, grading records and a final disposition of the crop were made.

Changes in internal appearance of the fruits were noted and photographed, and changes in juice content and composition were determined by laboratory tests.

\section{THESE ARE THE RESULTS:}

- Young, immature citrus fruits that are injured by frost make a more nearly complete recovery than do mature or nearly mature fruits. Under southern California conditions, therefore, Valencia oranges, young lemons, and even grapefruit have a better chance to recover than do navel oranges which usually are mature by the time of low temperatures. 
Favorable weather conditions following the nights of low temperatures apparently aided recovery.

Under the prevailing conditions of the spring, summer, and early fall of 1949, mature Valencia fruits in the test plots remained on the trees from early May until the middle of August without showing a decrease in quality. There was a small decrease in quality, however, from the middle of August to October 10 when the fruits were picked.

- Excessive peel thickness was not common among the test fruits. Albedo injury and surface injury to the peel were rare.

- The tests showed that either a stem-end cut or both a stem-end and center cut are necessary if the extent and severity of freeze injury in Valencias are to be determined accurately.

- A few more Valencia fruits were frozen in the stem end than in the center, many less were frozen in the stylar end than in either the stem end or center, and a much larger number of segments were frozen in the stem end than in either the center or stylar end.

- The water-soaked appearance, gray or milky color, and hesperidin crystals disappeared from the entire fruit, or a portion of it, within three months after it was frozen. This is also true of many of the gelatinized vesicles, although some remained in severely frozen fruits.

- Wavy segment walls and the light yellow, grainy condition of some vesicles did not disappear. Where hollow places occurred as a result of shrunken tissues in dead segments, the remaining, noninjured segments enlarged to fill, or partially fill, the spaces.

- Measurements of specific gravity of the fruit and measurements of juice on both a volume and a weight basis showed the $X$-ray and water separation on nonfrozen fruits to be more efficient than the separation by hand at the grading belt.

- The average milliliters and percentage of juice per fruit (frozen and nonfrozen), on a weight basis, increased as the 
season advanced, with the possible exception of the last test (October 10).

Total soluble solids and total sugars increased in both frozen and nonfrozen fruits from the time of the first test (February) until about the middle of August after which they began to decrease. The reducing sugars were more variable, but they also showed an upward trend. The concentration of soluble solids in the juice was not so high, nor were the acids so low, as in most years.

- The total free acids decreased rapidly in both frozen and nonfrozen fruits from February 28 to April 25, but very little thereafter. In several instances, there was a temporary increase after April 25.

- Granulation was much less severe in the 1949 Valencia crop than it is in most years. This is of special interest because many growers have thought that granulation is caused by low temperatures.

The response of both nonfrozen and frozen fruits to the effects of the different temperatures and humidities in the cold storage room and in the large, aerated room were not great enough to outweigh the natural differences that are always found in a series of samples from different sources.

\section{NOTE ON GRAPEFRUIT:}

- Freeze injury, based on number of frozen segments, was much more severe in grapefruit borne on the outside of the tree than in those borne on the inside.

- The concentrations of total soluble solids and total sugars were higher in nonfrozen than in frozen grapefruit, regardless of their position on the tree.

- There were no consistent differences in the concentrations of free acids in frozen and nonfrozen, "inside" and "outside" grapefruit.

The following pages contain a detailed discussion of the experiments and the results obtained, with supporting illustrations and tables.

A table of contents appears on the back cover. 


\section{FREEZE INJURY}

\section{AND SUBSEQUENT SEASONAL CHANGES IN VALENCIA ORANGES AND GRAPEFRUIT}

\section{E. T. BARTHOLOMEW}

\begin{abstract}
-
\end{abstract}
W. B. SINCLAIR

\author{
R. P. HORSPOOL
}

\section{WEATHER RECORDS}

The following Weather Station temperature readings are given as a general indication of the conditions that prevailed. The temperatures in the plots from which the test samples were taken may have been higher or lower than the Weather Station readings.

Most of the freeze injury occurred on the nights of January 3 to 7, 1949. The minimum temperatures on those nights were much below the freezing point at Placentia $\left(22.8^{\circ} \mathrm{F}\right.$ for $13 \mathrm{hrs}$. $)$, Fullerton $\left(23.2^{\circ} \mathrm{F}\right.$ for $14 \mathrm{hrs}$.), and Anaheim $\left(24.8^{\circ} \mathrm{F}\right.$ for $7 \mathrm{hrs}$. $)$, the areas from which the Valencia samples for this study were taken.

As noted, most of the freeze injury occurred on the nights of January 3 to 7 ,
1949 , but it is possible that some of the fruits were injured on the nights of December 23-24 and 24-25, 1948. At Placentia Weather Station No. 16, on the night of December 23-24, the temperature was $28^{\circ} \mathrm{F}$ for $5 \mathrm{hrs}$. and $20 \mathrm{~min}$., and $27^{\circ} \mathrm{F}$ for $2 \mathrm{hrs}$. and $10 \mathrm{~min}$. At Fullerton Station No. 19, the readings on the night of December $24-25$ were $28^{\circ} \mathrm{F}$ for $3 \mathrm{hrs}$, $15 \mathrm{~min}$., $27^{\circ} \mathrm{F}$ for $2 \mathrm{hrs}$., $2 \mathrm{~min}$., and $26^{\circ}$ $\mathrm{F}$ for $1 \mathrm{hr}{ }^{1}$

There were no heaters or wind machines in any of the groves from which the Valencia samples were taken.

\footnotetext{
${ }^{1}$ All weather records mentioned in this paper were furnished by Mr. Roy J. Rogers, meteorologist at the U. S. Department of Commerce Weather Bureau, Pomona, California.
}

NOTE: On February 7, 1949, several representatives of the citrus industry met at the University of California Citrus Experiment Station and asked that the Station undertake a study of the effects on citrus fruits of the freezing temperatures of the winter of 1948-1949. This publication is the result of such a study, and is Paper No. 649, University of California Citrus Experiment Station, Riverside, California.

\section{THE AUTHORS:}

Mr. Bartholomew is Professor of Plant Physiology and Plant Physiologist, Emeritus, in the Experiment Station, Riverside.

Mr. Sinclair is Biochemist in the Experiment Station, Riverside.

Mr. Horspool is Laboratory Technician in the Experiment Station, Riverside. 


\section{METHODS}

Several Valencia groves in northern Orange County were inspected repeatedly by packinghouse and field inspectors to determine approximate percentages of freeze injury. Following this, eight plots were selected, each from a different grove in the Placentia-Fullerton-Anaheim area. Each plot contained 25 trees. At the time the plots were chosen, four were supposed to show about 50 per cent and the other four about 25 per cent freeze injury in the fruit. None of the trees showed limb injury, but there was some damage to a few of the terminal leaves on new shoots in some of the plots.

The approximate ages of the Valencia trees in the eight plots were:

$\begin{array}{ccccccccc}\text { Plot: } & \text { A } & \text { B } & \text { C } & \text { D } & \text { E } & \text { F } & \text { G } & \text { H } \\ \text { Age: } & 35 & 69 & 34 & 21 & 27 & 32 & 21 & 21\end{array}$

The first samples of fruit were picked on February 28, 1949. Successive samples were picked every two weeks between that date and October 10, 1949. Each sample consisted of six fruits from each of the 25 trees -150 fruits from each plot at each picking. The fruits were not measured before picking, but were arbitrarily judged to be of medium size. The Valencias were outside fruits, and were taken from all sides of the trees and from the lowest branches to a height of about 6 feet. Grapefruit were taken similarly but from both outside and inside.

The fruits from each plot were mixed as they were put into a container in the grove. In the laboratory they were thoroughly mixed again so that they could be divided into two equal, representative lots of 75 each. The fruits to be used to determine the quantity and quality of the juice were wiped with a moist cloth to remove surface dirt, weighed, and then cut transversely in the center. (All cuts made in these studies were transverse.) As these fruits were cut, they were segregated into two groups called "nonfrozen" $(\mathrm{N})$ and "frozen" (F), and were weighed sepa- rately. The juice from the nonfrozen and frozen fruits was also measured and weighed separately. A large, electric hand reamer was used to extract the juice.

The second lot of 75 fruits was used to determine the severity of freeze injury and to detect granulation when, and if, it occurred. In the first half of the season, this was done by making three transverse cuts, one near the stem end, one in the center, and one near the stylar end of each fruit. In the second half of the season, a fourth cut was made, which passed just below the surface of the pulp at the stem end of the fruit. This was made to determine whether granulation was present. Separate records were made of (1) the total number of fruits showing freeze injury, (2) the number that showed injury in one portion only, (3) in two or more portions, and (4) the total number of segments injured in each portion.

For both Valencias and grapefruit, all analytical determinations, such as for soluble solids, acids, and sugars, were made on centrifuged juice. The total soluble solids and specific gravity of the juice were determined with a refractom. eter, the $\mathrm{pH}$ with a Beckman $\mathrm{pH}$ meter, the total acids by titration with a standard alkali solution and phenolphthalein indicator, and sugars by Blish's modified Hagedorn and Jensen method (1933, 1934).

During the course of these studies, 328 determinations each were made on refractive indexes, soluble solids, acids, $\mathrm{pH}$, reducing sugar, and total sugars. Actually, the total for the two sugars should be 1,312 since each was determined in duplicate. The average of those duplicate determinations is the value reported. In all of the tests with both Valencias and grapefruit, 31,270 fruits were used. Half of these were used for juice analysis, the other half to determine the severity of freeze injury. 


\section{RESULTS-VALENCIA ORANGES}

General observations.-In the following graphs and tables that refer to the quantity and quality of the juice, the fruits from which the juice was obtained are described as nonfrozen $(\mathrm{N})$ or frozen (F). This refers to the condition of the fruit at the center cut only. (The juice could not have been reamed from these fruits had they been cut at the ends as well as at the center.) To interpret these data properly it should be remembered that a fruit that showed freeze injury at the center cut may or may not have been frozen, little or much, in one or both ends, and that a fruit that did not show freeze injury at the center cut may have had no, little, or much injury in one or both ends.

To interpret the data from the lots of fruit that were used for reaming on a given date, see the data for the companion lot of fruits that were cut at the ends as well as the center, on the same date, to determine the severity and location of freeze injury in all parts of the fruit.

From the general observations that were made on Valencia fruits in the groves before the laboratory studies were begun, it was concluded that a fruit might show one or more of the following types of injury. (These comments apply primarily to groves in which approximately 50 per cent or less of the fruits were judged to be injured by low temperatures, and they apply to Valencias only.)

1. A water-soaked appearance indicated that the walls of many of the cells had become at least partially permeable and had permitted water to pass out of the cells into the intercellular and intervesicular spaces. After a few weeks, many of the fruits appeared to recover from this condition, indicating that the cells had been only temporarily changed and not killed. In fruits or parts of fruits where the cells had been killed, the water-soaked appearance gave way to drying and collapse of the tissues.
2. Often all, or a part, of the cut surface of the pulp had a pale gray or milky color, indicating that the carotenoid content (yellow pigments) of the cells had become partially depleted (fig. 1). The milky appearance in the pulp is said to have been found in nonfreeze years. This may be true, but in the fruits observed in these studies the condition was pronounced in the frozen and not in the nonfrozen fruits. It had largely disappeared by the last of March.

3. Hesperidin crystals were found mainly on the surfaces of two adjacent segment walls. These crystals appeared to be more abundant at some times than at others. They had practically disappeared by the latter part of March.

4. Some of the injured fruits had wavy or "snaky" segment walls (fig. 2). This condition is difficult to explain. In some cases, it appeared to have been caused by shrinkage of the pulp. In other cases, portions of the segment walls appeared to have gelatinized or grown and protruded into the adjacent tissues. Not all injured fruits had wavy segment walls, but when they occurred, they were usually much thicker than those in the uninjured fruit. In severe cases it was not uncommon to find gum pockets within these segments, most often in the narrow angles of the segments next to the central axis (fig. 3 ). Those who have made repeated observations on the development of the wavy segment wall state that at first it becomes water-soaked, gelatinous, and much thickened. Later, it becomes somewhat dehydrated and pale yellow in color but it never returns to its natural straightness, thickness, and color.

5. Another rather conspicuous type of injury was the development, in most any portion of the pulp, of vesicles (juice sacs) in various stages of gelatinization. In most cases these vesicles were isolated with not more than one to two or three 
Fig. 1.—Pale or "milky" appearance of the cut surface.

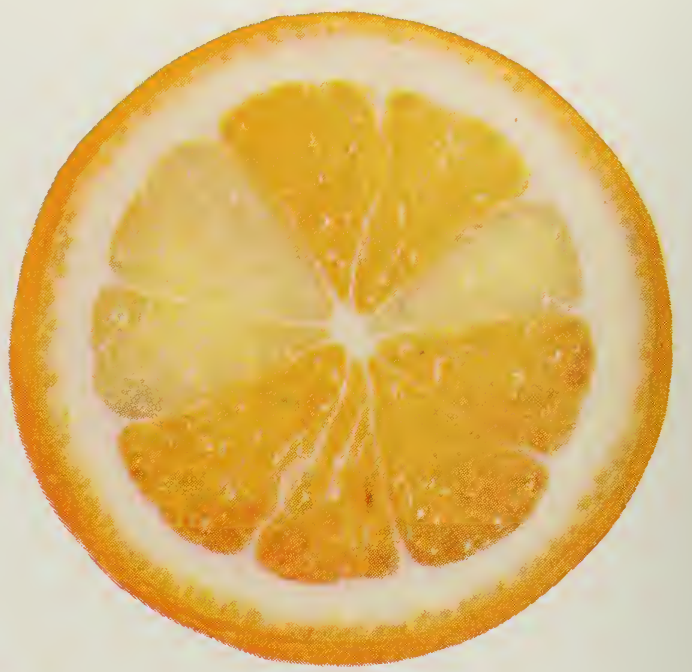

Fig. 2.-Wavy or "snaky" segment walls.

Fig. 3.-Gum pockets.

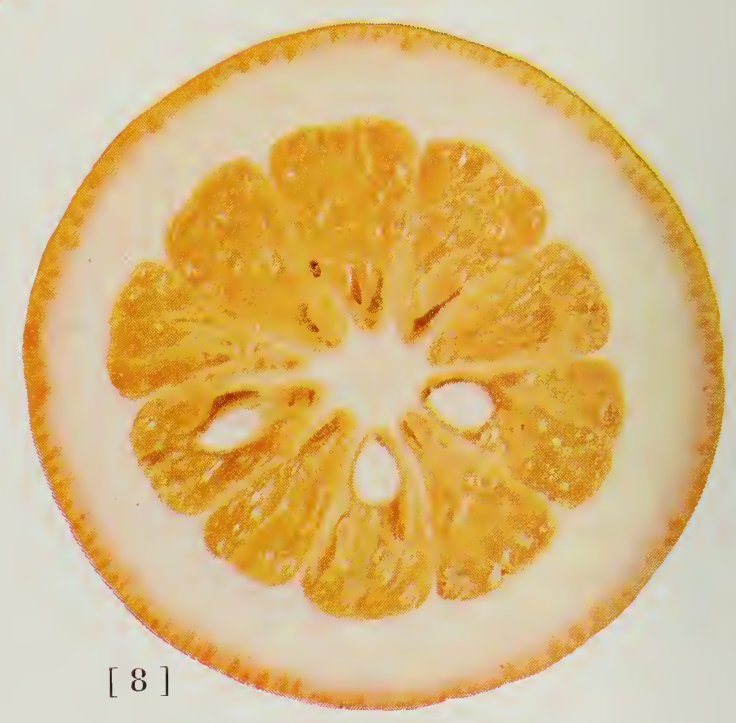

2

4 


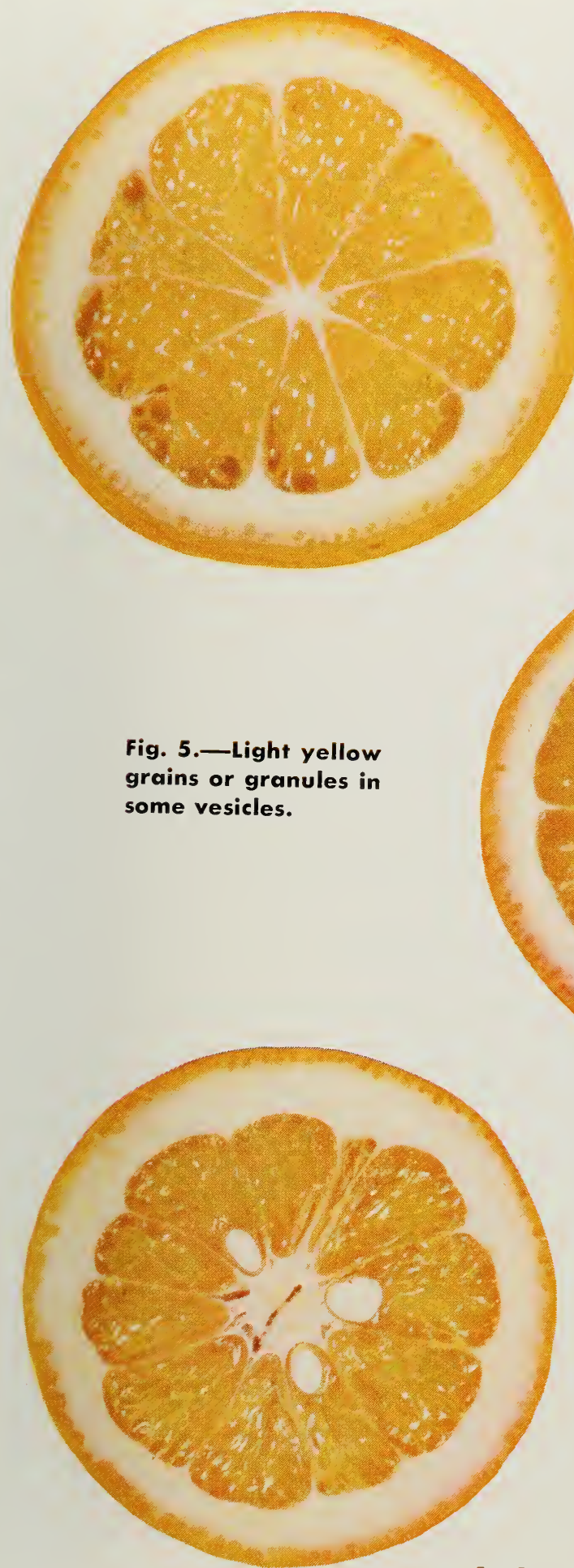

Fig. 5.-Light yellow grains or granules in some vesicles.

Fig. 4.- Scattered groups of gelatinized vesicles.

Fig. 6. Two segments formerly hollow but now filled or nearly filled in due to excessive growth of noninjured segments. 
adjoining each other. These vesicles appeared to be in the early stages of granulation (fig. 4). This condition, however, was seldom found in any of the fruits that were examined after the middle of April.

6. In the segments of some fruits, a few to several vesicles were partially or entirely killed. In many such fruits, not enough vesicles were injured in any one portion of a segment to cause any noticeable collapse. The injured portion of such vesicles had become light gray to yellow in color, and had a somewhat grainy appearance (fig. 5). There was no evidence that such vesicles recover.

7. Perhaps the most noticeable type of freeze injury was that in which all of the vesicles were killed in a part, or all, of one or more segments. In such cases, the vesicles lost water, collapsed, and left hollow spaces in the segments. Where only a portion of a segment, or even one or two entire segments, was injured, excessive growth in the uninjured segments often caused them to extend into the hollow spaces and fill, or almost fill, them (fig. 6) . Such growth conditions could occur in these fruits because they were immature when partially frozen.
8. Fruits rarely showed serious freeze injury on the surface of the peel. Such areas were characterized by the usual drying, shrinking, and toughening and by a light to chestnut brown color in small or large patches, caused by the oil which escaped from the injured oil glands. Other types of surface injury to the peel were: lack of luster, retention of green color, sometimes an excessive regreening, localized ridges and bumps, or general coarseness and a flattening of the peel directly outside the injured pulp tissues.

While exact peel thickness data were not obtained, general observation led to the conclusion that only a relatively few of the fruits used in these studies had excessively thick peels as a result of freeze injury. These were on the fruits that were frozen in all or nearly all portions of the pulp. On the fruits in which half or less of the pulp had been frozen, there was very little, if any, excessive thickening of the peel.

9. No visible injury could be detected in the albedo (white portion of the peel) of any of the fruits.

\section{LABORATORY TESTS}

Total freeze injury in all parts of fruits tested. - The total percentages of Valencia fruits frozen in at least one segment or portion of a segment, at each of the seventeen tests between February 28 and October 10, 1949, are shown in Table 1. The values for four of the plots-those in which the fruits were most severely injured-are given in Figure 7. Both the table and the figure represent the averages for 75 fruits from each plot on each date. The total amounts of freeze injury in the fruits decreased as the season advanced. For example, the maximum in Plot D was 73.3 per cent on March 14, the minimum, 26.7 per cent on October 10; in Plot $\mathrm{H}$, the maximum was 36.0 per cent on March
14, the minimum, 2.7 per cent on both September 26 and October 10. As would be expected in random sampling, the percentage of freeze injury in the fruits on different dates varied considerably. For example, the amount of injury in Plot A was 50.7 per cent on August 1, only 33.3 per cent on the preceding date (July 18), and 38.7 per cent on the following date (August 15). No single factor accounts for the general decrease in the percentage of fruits that showed freeze injury as the season advanced. Some of the fruits dropped, but tests in the early part of the season showed that these were about equally divided between frozen and nonfrozen. Further tests of this nature were 
not made during the remainder of the season. In taking all samples, an effort was made to select exposed, outside fruit only, but toward the end of the season, especially on trees that had the least amount of fruit, some fruits had to be chosen that had been at least partially protected by foliage. It is of interest to note, however, that the same general decrease in injury was found in fruits from plots where an abundance of outside fruits remained on all of the trees at the end of the season (October 10). A third explanation is that by far the greater percentage of the fruits from all plots showed recovery. In some fruits, the recovery was only partial, in others almost complete, in so far as juice quantity and quality were concerned. In some fruits, the adjoining segments had enlarged abnor- mally so that they had filled or almost filled the hollow of the injured segment (fig. 6).

It is also of interest here to note that after about the middle of March, relatively few fruits, nonfrozen or frozen, dropped from the trees in any of the plots, even fewer than in some years when there had been no freeze injury. In general, this condition prevailed in all of the groves in the area where the test plots were located. ${ }^{2}$

${ }^{2}$ Observations to date (middle of March, 1950) have shown that the drop of both nonfrozen and frozen fruits has been much more severe following the freezes in early January of this year (1950) than it was following the freezes of late December, 1948, and early January, 1949. There are some exceptions, but this condition appears to apply quite generally to all of southern California.

TABLE 1-Percentages of Valencia Fruits that Showed at Least One Frozen Segment in One or More Portions of the Fruit ${ }^{1}$

FEBRUARY 28 TO OCTOBER 10, 1949

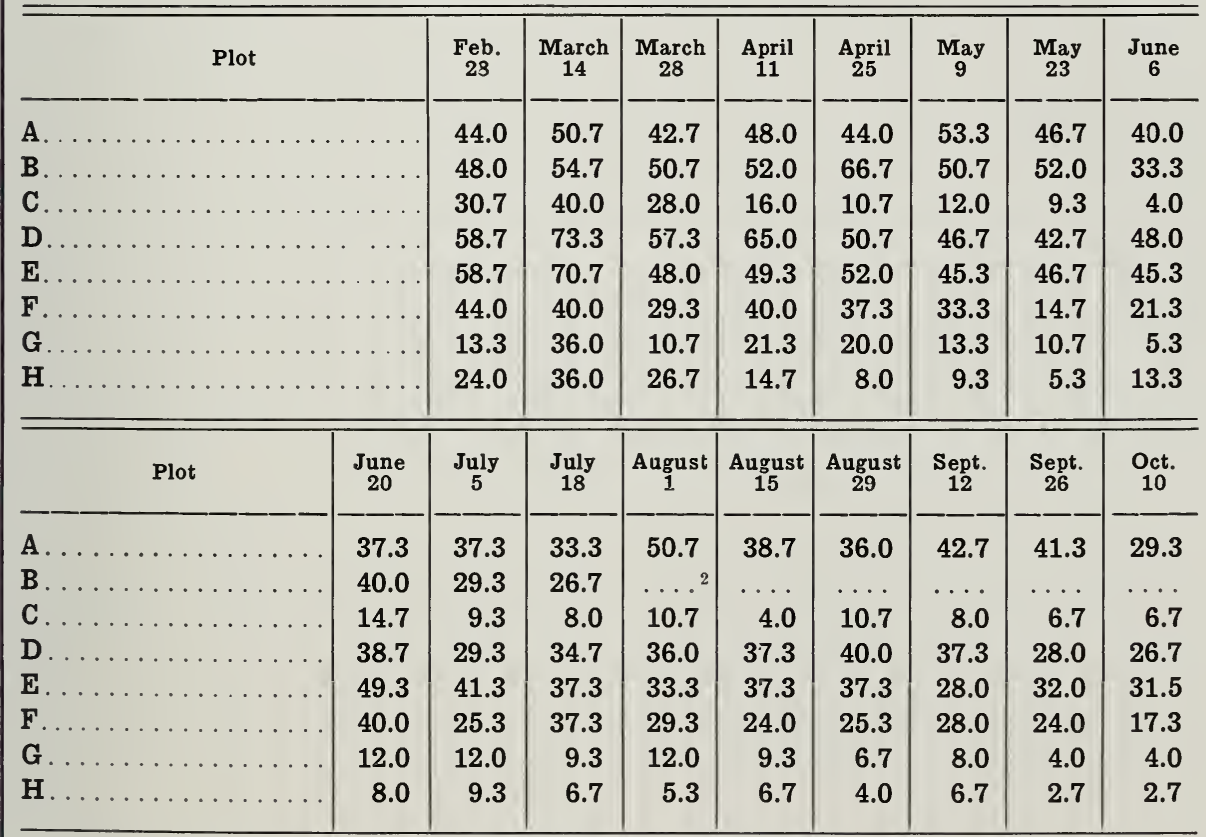

Based on 75 fruits from each plot on each date, a total of 9,750 fruits

2 Plot picked by mistake. 


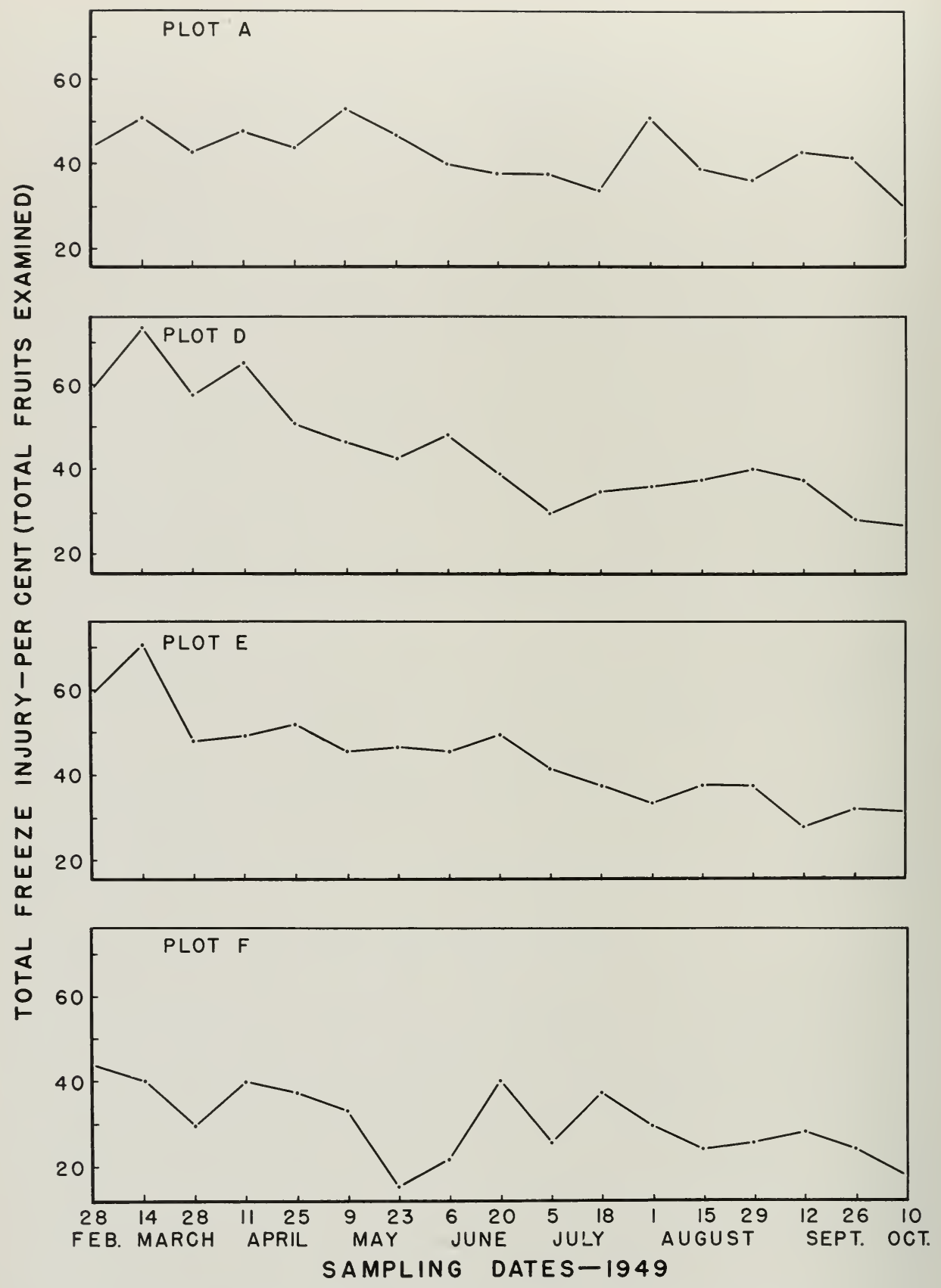

Fig. 7.-Percentages of freeze injury in Valencia oranges as the season advanced.

(See table 1 for these and other values.) 
Fruits frozen in one portion only.-Freeze injury was found in only one portion of some of the fruits, that is, in either the stem end, the center, or in the stylar end (table 2). With the exception of those from plots $\mathrm{C}, \mathrm{G}$, and $\mathrm{H}$, about as many fruits showed freeze injury in one portion only at the close of the season as at the beginning. All plots except $B$ and D had more fruits frozen in the stem end than in either the center or the stylar end. In all, 1,431 (14.7 per cent) out of 9,750 fruits were frozen in one portion only. The injury in a given portion of a fruit was often confined to a single segment, but in the same portion of other fruits, several or even all segments were frozen. As shown in Table 2, fewer segments were frozen in the stylar end than in either the stem end or the center.

\section{Fruits frozen in one or more por-} tions. - Table 3 shows, for each plot, the total numbers and percentages of fruits frozen in the stem end only, center only, stylar end only, and in the following combinations: stem end + center; stem end + stylar end; center + stylar end; and stem end + center + stylar end. The data in this table thus give a complete picture of the total number of fruits frozen and the location of the injury. There is no duplication. A fruit that is counted in one group is not counted in any other. The table shows that Plots C, F, G, and $\mathrm{H}$ had the greatest number of fruits frozen in the stem end, Plot B in the center, Plot E in the stem end + center, and Plots A and $D$ in the stem end + center + stylar end. Figure 8 shows this for Plots A, D, E, and $F$, which had the greatest amount of freeze injury. Note the marked differences in values for a given plot and in values for the different plots.

Referring to the total number of frozen fruits for each plot (next to last column in table 3), we find that the two groups which had the greatest number of frozen fruits ( 1 and 4 ) were the stem end only
(650 fruits) and the stem end + center only (679 fruits). Approximately 47 per cent of the frozen fruits were in these two groups. Of further interest is the fact that the total number of fruits frozen in the stem end (groups 1, 4, 5, and 7) was a little greater than the total number frozen in the center (groups 2, 4, 6, and 7)1,952 and 1,897 , respectively.

Severity of freeze injury.-The data in Table 4 and Figure 9 have been so arranged as to divide the degrees of freeze injury to Valencia fruits into two groups. The first half of the table and the cross-hatched portion of the columns in the figure deal with fruits in which two or fewer segments were frozen. The second half of the table and the open portions of the columns in the figure deal with fruits in which three or more segments were frozen. Referring to the table and the figure for the first group, we find that more fruits and more segments were frozen in the center than in either the stem end or stylar end. Three individual plots, however, D, G, and H (table 4), showed higher totals for the stem end than for the center.

In the second group, there were 131 more fruits and 1,098 more segments frozen in the stem end than in the center. Only one plot (B) had more fruits frozen in the center than in the stem end. In all plots, the stem end had the greatest number of frozen segments. In both groups, the total numbers of fruits and segments frozen in the stylar end were much lower than those in the other two portions of the fruit. Considering all individual tests for all plots (130 tests, 75 fruits each), there were only 15 instances in which the greatest number of fruits were found to be frozen in the stylar end, and only 10 instances in which the greatest number of frozen segments were found in that portion.

Adding the numbers of frozen fruits in the first group in Table $4(2,644)$ to those in the second group $(2,156)$ would 


\begin{tabular}{|c|c|c|c|c|c|c|c|c|c|c|}
\hline \multirow{6}{*}{ 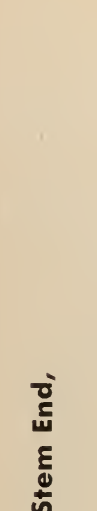 } & \multirow{2}{*}{  } & 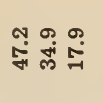 & 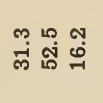 & 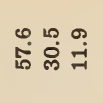 & 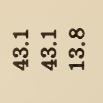 &  & 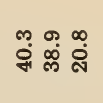 &  &  & \\
\hline & & 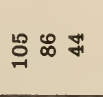 & เำ ธี వి & œ & క్త క్స లే & 규 융 & 心 & ชำ 옹ㅇ & 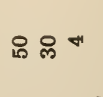 & \\
\hline & ثું어 & N & : & $N \neg N$ & - so &  & $m \sim N$ & N 00 & N 00 & \\
\hline & 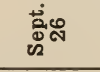 & mor & : : : & Noo & On & $\Rightarrow न-1$ & on m & toO & too & \\
\hline & 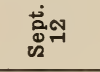 & ᄋ $0 न$ & : & $m \infty$ & $\mathcal{\sim}$ & $\forall \forall$ & $\infty न \infty$ & no 0 & $m \rightarrow 0$ & \\
\hline & ᄅై & N & & $m \infty$ & เo 우 & r 이 & $\sim \forall$ & N 00 & $H \infty O$ & \\
\hline$\frac{1}{2}$ & 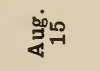 & $\Rightarrow$ is 0 & & NOO & H & $-\infty 0$ & $\omega \mathrm{N} r$ & NoO & $\rightarrow$ ન૦ & \\
\hline ธ & $\stackrel{\dot{0}}{\dot{z}}-1$ & $0 \infty r$ & ^: & $\sim N N$ & מم & $\infty न$ & D & ००न & no 0 & \\
\hline & 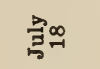 & $\forall$ 어 & $\forall-0$ & $m \infty-1$ & ס & $\infty \bullet-r$ & $\infty \cup \infty$ & to 00 & N N & \\
\hline 등 & 疍 & מ & $\forall \infty-r$ & m & $0=0$ & $\theta 0$ o & $\forall$ N & NO & 000 & \\
\hline$\frac{2}{d} \frac{1}{\frac{1}{2}}$ & క్రైన్ & $\infty$ ட & $-0-1$ & 웅ㄱ & OD N & 10 00 & o억 & Noo & NoO & \\
\hline$\div \frac{2}{5}$ & ڤ్ & Lo $0 \mathrm{~m}$ & $0 \sim N$ & Oन & $0 \sim m$ & 우 $0 न$ & $H=0$ & moo & L 0 o 0 & \\
\hline एक & స్తైణ & $\rho_{-1}^{\infty}$ & ص m & L N O & $\infty$ N m & 000 & N 00 & $m \infty$ & noo & $\$$ \\
\hline & 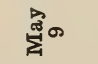 & -n & เ & 0 Ho & or & $00 \mathrm{~N}$ & מ & N & 000 & 胥 \\
\hline & 橧禺 &  & $\infty \circ$ & N N 0 & $m \sim-r$ & L & ๓ & ద & O- 0 & 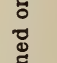 \\
\hline है & 萦न & or & $n \sim \infty$ & 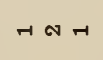 & 유 & H ब न & $\omega \infty$ &  & N $\rightarrow 0$ & 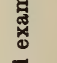 \\
\hline I & క్త్రై & $W \sim \infty$ & $n=0$ & $\infty \infty \sim$ & ద & ○ & 0 on & H ન૦ & $\infty$ ద & $\vec{z}$ \\
\hline щّ & 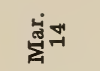 & N 10 & $m$ m & o n & $\infty \sim \infty$ & $m \sim$ & "우 ㅎ & $\rightarrow \infty$ & $\infty \Rightarrow-1$ & $\begin{array}{l}\$ \\
\vdots\end{array}$ \\
\hline & 这㐫 & $\alpha$ D R & $\infty \underset{\sim}{ }$ & एव & n & $00 \mathrm{~m}$ & L 00 & ON & $\infty \pi$ & త్ \\
\hline & 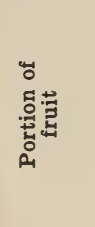 & 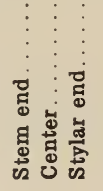 & 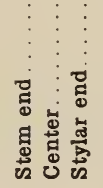 & 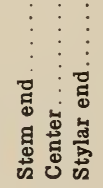 &  & 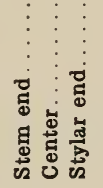 & 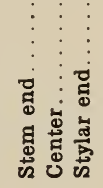 & 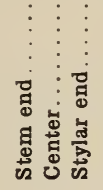 &  & 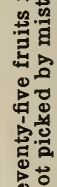 \\
\hline & $\stackrel{\overrightarrow{0}}{\mathrm{~m}}$ & 4 & $\infty$ & 0 & A & 国 & 臣 & 0 & 资 & \\
\hline
\end{tabular}


give a total of 4,800 fruits frozen instead of 2,845 . The fruits in Table 4 were not segregated as in Table 3 , and therefore there were a large number of duplications. For example, one fruit may have had frozen segments in both the stem and center portions, and another fruit may have had them in all three portions. Auto. matically, the first fruit would be counted twice and the other fruit three times (see fig. 10, p. 19).

The extent and location of freeze injury in the Valencias from all eight plots are shown in Figure 10, $\mathrm{R}$ to $\mathrm{Y}$. The shaded areas represent the portion or portions of the fruit that were frozen. The number of fruits and of segments frozen in a given portion of the fruit is shown by the figures within the shaded areas, fruits at the left and segments at the right. For example, $R$ shows that 650 fruits were frozen in the stem end only and that in the stem end of these 650 fruits there were 1,461 frozen segments; V represents 82 fruits that were frozen in the stem and stylar ends only, with 201 frozen segments in the former and 137 in the latter. Y shows the total number of fruits frozen and the total number of frozen segments in each portion of the fruit.

The findings reported in this section and in the three sections above may have an important bearing on our present manner of testing Valencia fruits to determine the percentage of freeze injury. This point will be treated more fully in the discussion.

Volume of juice per fruit.-The average volumes (ml.) of juice per nonfrozen and frozen fruits (table 5 and fig. 11 for Plots A, D, E, and F) are based on measurements of the juice just as it came from the reamer. The reamer has a strainer but the openings in it are large enough to permit the passage of whole juice sacs and bits of other tissues of similar size. In other words, the juice measured was like that offered to the consumer at a fruit juice stand. The juice

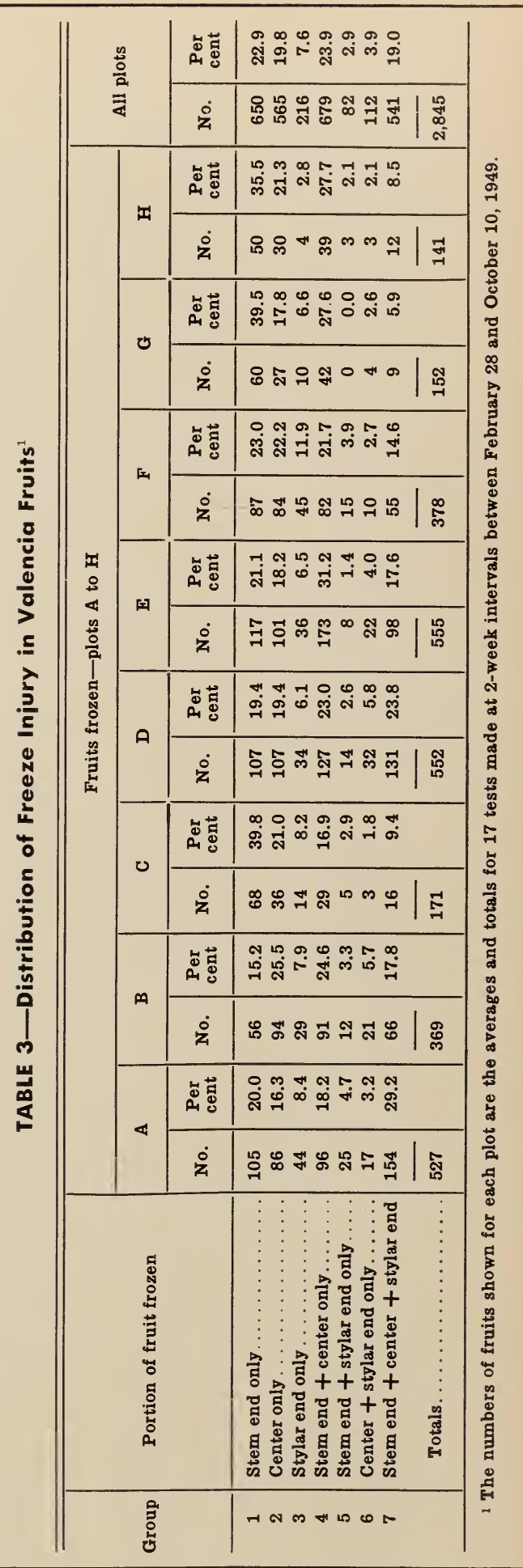






Fig. 8.-Distribution of freeze injury in Valencia oranges. (See table 3 for these and other values.)

was thoroughly stirred just before measuring. Because the presence of the tissues in the juice made the volume somewhat difficult to read, its exactness was checked by weighing each lot of juice. A comparison of the two sets of values showed that those given for volume on a milliliter basis are approximately correct. These are given in the table, therefore, because they are more common and more easily interpreted. Attention is called to the fact, however, that the presence of a considerable quantity of pulp tissue in the juice gives higher values in Tables 5 and 6, than if most of the tissues had been screened out, as is done commercially, before the juice was measured and weighed. It should also be noted that, although they may be somewhat high, the values for both nonfrozen and frozen fruits were obtained in the same manner and are therefore comparable.

The values presented in Table 5 and Figure 11 show that the nonfrozen fruits contained 5 to 25 per cent more juice than did the frozen ones. In all of the lots that contained frozen fruits there were, however, 24 instances in which the average weight of the frozen fruits was equal to or greater than that of the nonfrozen fruits. Nevertheless, in all of these instances the nonfrozen fruits contained more juice per fruit than did those that were frozen. The fact that the weight of a frozen fruit was less than that of a nonfrozen does not necessarily mean that the frozen fruit was the smaller. A large, badly frozen fruit may weigh less than a considerably smaller, nonfrozen one. The data in Table 5 show that a fruit sample with a total 
freeze injury of 45 per cent may have a juice content equal to 43 per cent of its weight, while a sample with only 28 per cent freeze injury may have a juice content equal to only 37 per cent of its weight. Again, a fruit that shows no freeze injury at the center cut may have less juice than one frozen at the center. The results emphasize the need to determine the severity of freeze injury in all portions of the fruit. As will be brought out later, the variations in specific gravity, even in noninjured fruits, were probably a factor in causing this condition.

There were variations in the amounts of juice per fruit from the different plots on successive sampling dates but, in general, there was a gradual increase. In four instances, the amounts of juice per fruit on October 10 were twice those of February 28. Two of these instances (plots A and D) were in frozen fruit and

TABLE 4-Different Degrees of Freeze Injury in Valencia Orange Fruits ${ }^{1}$

\begin{tabular}{l|l|l|c|c|c|c|c|c|c}
\hline \multirow{2}{*}{ Plot } & \multicolumn{3}{|c|}{$\begin{array}{c}\text { No. fruits } \\
\text { frozen in: }\end{array}$} & \multicolumn{3}{c|}{$\begin{array}{c}\text { No. segments } \\
\text { frozen in: }\end{array}$} & \multicolumn{2}{c}{$\begin{array}{c}\text { Av. no. frozen segments per } \\
\text { portion of fruit }\end{array}$} \\
\cline { 2 - 7 } & $\begin{array}{c}\text { Stem } \\
\text { end }\end{array}$ & Center & $\begin{array}{c}\text { Stylar } \\
\text { end }\end{array}$ & $\begin{array}{c}\text { Stem } \\
\text { end }\end{array}$ & Center & $\begin{array}{c}\text { Stylar } \\
\text { end }\end{array}$ & $\begin{array}{c}\text { Stem } \\
\text { end }\end{array}$ & Center & $\begin{array}{c}\text { Stylar } \\
\text { end }\end{array}$ \\
\hline
\end{tabular}

Not more than two segments frozen

\begin{tabular}{|c|c|c|c|c|c|c|c|c|c|}
\hline A. & 154 & 186 & 134 & 234 & 280 & 204 & 1.5 & 1.5 & 1.5 \\
\hline B & 130 & 149 & 94 & 215 & 235 & 134 & 1.7 & 1.6 & 1.4 \\
\hline C. & 65 & 46 & 24 & 103 & 77 & 28 & 1.6 & 1.7 & 1.2 \\
\hline D. & 182 & 195 & 136 & 279 & 293 & 203 & 1.5 & 1.5 & 1.5 \\
\hline E. & 182 & 192 & 116 & 288 & 290 & 178 & 1.6 & 1.5 & 1.5 \\
\hline F. & 126 & 150 & 104 & 188 & 242 & 161 & 1.5 & 1.6 & 1.5 \\
\hline G & 65 & 60 & 21 & 98 & 83 & 22 & 1.5 & 1.4 & 1.1 \\
\hline $\mathbf{H}$ & 55 & 57 & 21 & 90 & 81 & 28 & 1.6 & 1.5 & 1.3 \\
\hline \multirow{3}{*}{$\begin{array}{l}\text { All plots: } \\
\text { Number. } \\
\text { Per cent.. }\end{array}$} & & & & & & & & & \\
\hline & 959 & 1,035 & 650 & 1,495 & 1,681 & 958 & 1.6 & 1.6 & 1.5 \\
\hline & 36.3 & 39.1 & 24.6 & 36.2 & 40.6 & 23.2 & $\ldots$ & $\ldots$ & $\ldots$ \\
\hline
\end{tabular}

Three or more segments frozen

\begin{tabular}{|c|c|c|c|c|c|c|c|c|c|}
\hline A. & 216 & 171 & 103 & 1,068 & 765 & 441 & 4.9 & 4.5 & 4.3 \\
\hline$\ldots$ & 97 & 131 & 47 & 461 & 453 & 168 & 4.8 & 3.5 & 3.5 \\
\hline C. & 52 & 37 & 14 & 223 & 160 & 56 & 4.3 & 4.3 & 4.0 \\
\hline D. & 206 & 193 & 73 & 954 & 825 & 306 & 4.6 & 4.3 & 4.2 \\
\hline E. & 215 & 193 & 40 & 1,065 & 800 & 153 & 5.0 & 4.1 & 3.8 \\
\hline F. & 108 & 81 & 20 & 465 & 328 & 92 & 4.3 & 4.0 & 4.6 \\
\hline G. & 49 & 28 & 4 & 196 & 112 & 20 & 4.0 & 4.0 & 5.0 \\
\hline $\mathrm{H}$. & 50 & 28 & 0 & 218 & 109 & 0 & 4.4 & 3.9 & 0.0 \\
\hline $\begin{array}{l}\text { All plots : } \\
\text { Number }\end{array}$ & 993 & 862 & 301 & 4.650 & 3.552 & 1.236 & 4.7 & 4.1 & 4.1 \\
\hline Per cent... & 46.0 & 40.0 & 14.0 & $\begin{array}{r}49.3 \\
\end{array}$ & 37.6 & $\begin{array}{r}1320 \\
13.1\end{array}$ & $\ldots$ & $\ldots$ & $\ldots$ \\
\hline
\end{tabular}

1 A total of 9,750 fruits examined. 


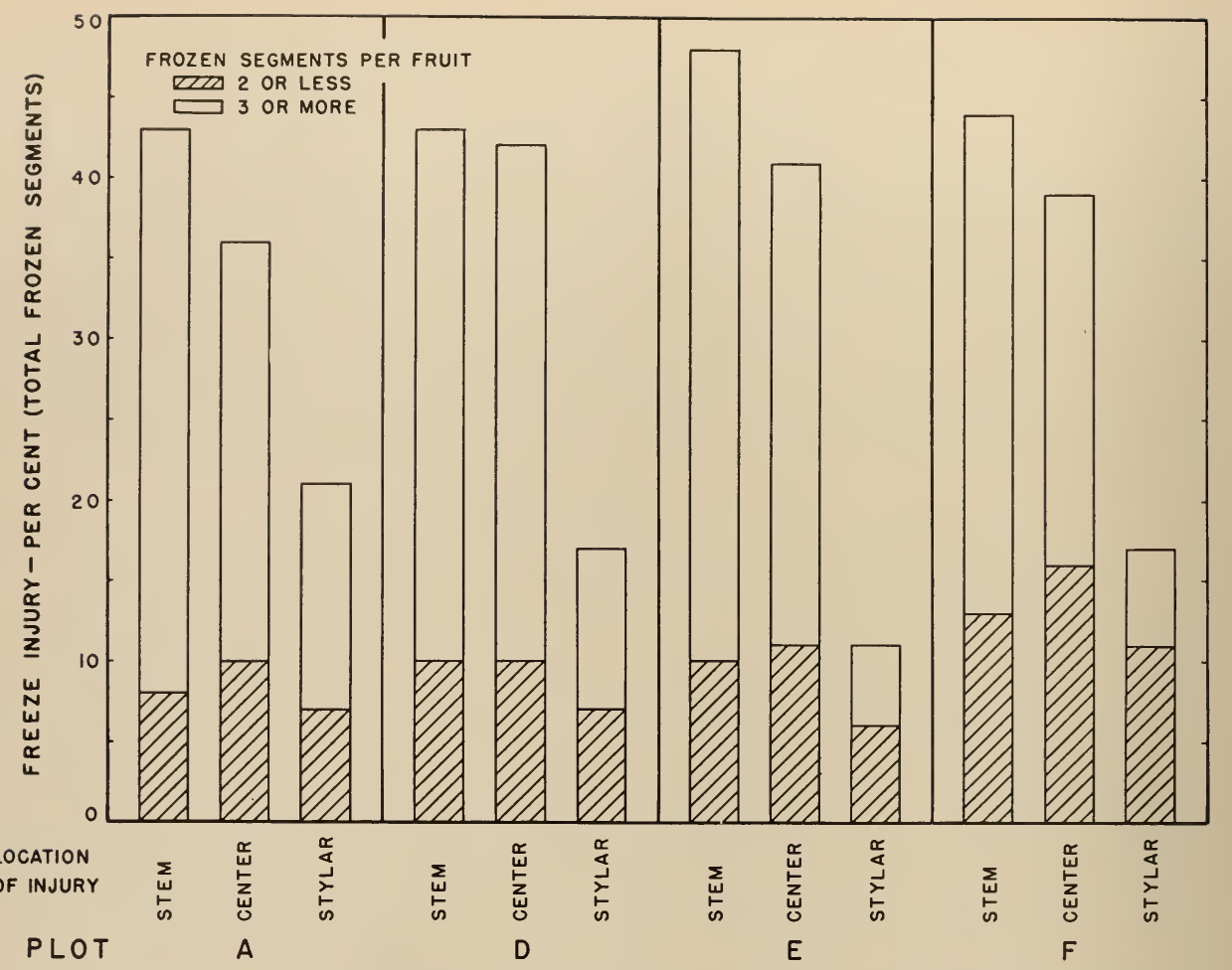

Fig. 9.-Different degrees of freeze injury based on number and location of frozen segments in different portions of the fruit. (See table 4 for these and other values.)

two (plots $\mathrm{G}$ and $\mathrm{H}$ ) in nonfrozen. The amount of juice per fruit increased as the season advanced because of the normal increase in size of fruit, the normal increase in percentage of juice vs. tissues, and the recovery, or filling in, of some of the frozen segments (fig. 6). It should be noted that some of this increase may have shown up as a result of error in selecting samples. Although care was taken to choose medium-sized fruits for each sample, it is possible that, as the season advanced, the fruits chosen may have been slightly above average.

NOTE: The terms "nonfrozen" and "frozen," as used in this section, refer to condition of fruits exposed by the center cut only.

Juice-per cent of weight of fruit.-From February 28 to August 29, there was a general increase in the per- centage of juice in the fruits on a weight basis (table 6 and fig. 12 for plots A, D, E, and F). After August 29, there was no definite increase. Between those two dates, the increase for the nonfrozen fruits ranged from 20 to 42 per cent, that for the frozen (counting only plots A, D, E, and $F$ ), from 30 to 56 per cent. In these four plots, the amount of juice in the frozen fruits increased an average of 38 per cent; in the nonfrozen, the increase was only 28 per cent. The data thus show that the frozen fruits made an appreciable recovery. Since the values in Table 6 are in terms of per cent of weight of fruits, they can be easily converted to pounds of juice per ton of fruit.

The amounts of juice in the fruits from the eight plots were not determined on a volume-per-fruit basis, but on a weight basis only (table 6 and fig. 12). The 
NUMBER OF FROZEN FRUITS AND SEGMENTS


Fig. 10.-Diagrammatic representation of the number of fruits and segments frozen in each of the three different portions of the fruit-stem end, center, and stylar end. 
TABLE 5-Yields of Juice from Nonfrozen and Frozen Valencia Oranges (MI. per Fruit)

\begin{tabular}{|c|c|c|c|c|c|c|c|c|c|c|}
\hline Plot & \multicolumn{2}{|c|}{$\begin{array}{l}\text { Condition } \\
\text { of fruit }\end{array}$} & $\begin{array}{c}\text { Feb. } \\
28\end{array}$ & $\underset{14}{\operatorname{March}}$ & $\underset{28}{\operatorname{March}}$ & $\begin{array}{c}\text { April } \\
11\end{array}$ & $\begin{array}{c}\text { April } \\
25\end{array}$ & $\underset{9}{\operatorname{May}}$ & $\underset{23}{\text { May }}$ & $\underset{6}{\text { June }}$ \\
\hline $\mathbf{A}$ & \multicolumn{2}{|l|}{$\begin{array}{l}\mathbf{N}^{1} \\
\mathbf{F}^{1} \ldots\end{array}$} & $\begin{array}{c}\mathrm{ml} \\
44 \\
33\end{array}$ & $\begin{array}{l}\mathrm{ml} . \\
48 \\
36\end{array}$ & $\begin{array}{l}\mathrm{ml} . \\
51 \\
41\end{array}$ & $\begin{array}{l}\mathrm{ml} \\
52 \\
\mathbf{4 5}\end{array}$ & $\begin{array}{l}\mathrm{ml} . \\
53 \\
48\end{array}$ & $\begin{array}{c}\mathrm{ml} . \\
55 \\
48\end{array}$ & $\begin{array}{c}\mathrm{ml} \\
59 \\
50\end{array}$ & $\begin{array}{c}\mathrm{ml} \\
55 \\
44\end{array}$ \\
\hline B & & $\begin{array}{l}44 \\
36\end{array}$ & $\begin{array}{l}45 \\
35\end{array}$ & $\begin{array}{l}46 \\
36\end{array}$ & $\begin{array}{l}49 \\
40\end{array}$ & $\begin{array}{l}57 \\
41\end{array}$ & $\begin{array}{l}57 \\
46\end{array}$ & $\begin{array}{l}58 \\
49\end{array}$ & $\begin{array}{l}55 \\
45\end{array}$ \\
\hline C & & $\begin{array}{l}46 \\
36\end{array}$ & $\begin{array}{l}48 \\
34\end{array}$ & $\begin{array}{l}55 \\
37\end{array}$ & $\begin{array}{l}57 \\
38\end{array}$ & $\begin{array}{l}61 \\
.^{3}\end{array}$ & $\begin{array}{l}64 \\
\ldots\end{array}$ & $\begin{array}{l}68 \\
\ldots\end{array}$ & $\begin{array}{l}64 \\
\ldots\end{array}$ \\
\hline D & & $\begin{array}{l}40 \\
31\end{array}$ & $\begin{array}{l}40 \\
35\end{array}$ & $\begin{array}{l}44 \\
37\end{array}$ & $\begin{array}{l}51 \\
40\end{array}$ & $\begin{array}{l}54 \\
41\end{array}$ & $\begin{array}{l}60 \\
45\end{array}$ & $\begin{array}{l}60 \\
47\end{array}$ & $\begin{array}{l}53 \\
46\end{array}$ \\
\hline $\mathbf{E}$ & \multicolumn{2}{|l|}{$\begin{array}{l}\text { N. } \\
\text { F. }\end{array}$} & $\begin{array}{l}35 \\
34\end{array}$ & $\begin{array}{l}38 \\
31\end{array}$ & $\begin{array}{l}40 \\
33\end{array}$ & $\begin{array}{l}44 \\
40\end{array}$ & $\begin{array}{l}48 \\
43\end{array}$ & $\begin{array}{l}47 \\
37\end{array}$ & $\begin{array}{l}54 \\
43\end{array}$ & $\begin{array}{l}49 \\
40\end{array}$ \\
\hline$F$ & & $\begin{array}{l}52 \\
38\end{array}$ & $\begin{array}{l}52 \\
35\end{array}$ & $\begin{array}{l}57 \\
49\end{array}$ & $\begin{array}{l}55 \\
42\end{array}$ & $\begin{array}{l}63 \\
39\end{array}$ & $\begin{array}{l}62 \\
53\end{array}$ & $\begin{array}{l}68 \\
54\end{array}$ & $\begin{array}{l}58 \\
46\end{array}$ \\
\hline G & & 45 & 46 & $\begin{array}{l}53 \\
39\end{array}$ & 59 & $\begin{array}{l}60 \\
43\end{array}$ & 65 & 67 & 67 \\
\hline $\mathbf{H}$ & \multicolumn{2}{|l|}{$\begin{array}{l}\mathbf{N} . \\
\mathbf{F} .\end{array}$} & $\begin{array}{l}45 \\
33\end{array}$ & $\begin{array}{l}47 \\
30\end{array}$ & $\begin{array}{l}50 \\
38\end{array}$ & $\begin{array}{l}57 \\
\ldots 3\end{array}$ & $\begin{array}{l}59 \\
\ldots\end{array}$ & $\begin{array}{l}60 \\
\ldots\end{array}$ & $\begin{array}{l}63 \\
\ldots\end{array}$ & $\begin{array}{l}67 \\
\ldots\end{array}$ \\
\hline Plot & $\begin{array}{c}\text { Condition } \\
\text { of fruit }\end{array}$ & $\underset{20}{\text { June }}$ & July & $\underset{18}{\text { July }}$ & August & $\underset{15}{\text { August }}$ & $\underset{29}{\text { August }}$ & $\begin{array}{c}\text { Sept. } \\
12\end{array}$ & Sept. & Oct. \\
\hline $\mathbf{A}$ & $\begin{array}{l}\mathbf{N}^{1} \ldots \\
\mathbf{F}^{1} \ldots\end{array}$ & $\begin{array}{c}\mathrm{ml} . \\
60 \\
52\end{array}$ & $\begin{array}{c}\mathrm{ml} . \\
64 \\
58\end{array}$ & $\begin{array}{l}\mathrm{ml} . \\
67 \\
56\end{array}$ & $\begin{array}{l}\text { ml. } \\
65 \\
54\end{array}$ & $\begin{array}{l}\mathrm{ml} . \\
68 \\
56\end{array}$ & $\begin{array}{l}\text { ml. } \\
69 \\
55\end{array}$ & $\begin{array}{l}\text { ml. } \\
70 \\
61\end{array}$ & $\begin{array}{l}\mathrm{ml} . \\
72 \\
60\end{array}$ & $\begin{array}{l}\text { ml. } \\
74 \\
69\end{array}$ \\
\hline B & $\begin{array}{l}\text { N. } \\
\text { F. }\end{array}$ & $\begin{array}{l}60 \\
52\end{array}$ & $\begin{array}{l}60 \\
55\end{array}$ & $\begin{array}{l}60 \\
55\end{array}$ & $\ldots^{2}$ & . & . & $\begin{array}{l}. \\
.\end{array}$ & $\begin{array}{l}. \\
\ldots\end{array}$ & $\begin{array}{l}. \\
\ldots\end{array}$ \\
\hline C & $\begin{array}{l}\text { N. } \\
\text { F. }\end{array}$ & 69 & 76 & 71 & 74 & $\begin{array}{l}76 \\
. .\end{array}$ & 79 & $\begin{array}{l}78 \\
\ldots\end{array}$ & 80 & $\begin{array}{l}80 \\
\ldots\end{array}$ \\
\hline D & $\begin{array}{l}\text { N. } \\
\text { F. }\end{array}$ & $\begin{array}{l}65 \\
61\end{array}$ & $\begin{array}{l}66 \\
55\end{array}$ & $\begin{array}{l}64 \\
61\end{array}$ & $\begin{array}{l}74 \\
65\end{array}$ & $\begin{array}{l}74 \\
61\end{array}$ & $\begin{array}{l}74 \\
69\end{array}$ & $\begin{array}{l}71 \\
60\end{array}$ & $\begin{array}{l}74 \\
68\end{array}$ & $\begin{array}{l}78 \\
62\end{array}$ \\
\hline $\mathbf{E}$ & $\begin{array}{l}\mathbf{N} \\
\mathbf{F}\end{array}$ & $\begin{array}{l}54 \\
47\end{array}$ & $\begin{array}{l}56 \\
50\end{array}$ & $\begin{array}{l}56 \\
46\end{array}$ & $\begin{array}{l}55 \\
46\end{array}$ & $\begin{array}{l}59 \\
48\end{array}$ & $\begin{array}{l}65 \\
56\end{array}$ & $\begin{array}{l}60 \\
53\end{array}$ & $\begin{array}{l}61 \\
52\end{array}$ & $\begin{array}{l}62 \\
55\end{array}$ \\
\hline $\mathbf{F}$ & $\begin{array}{l}\mathbf{N} \\
\mathbf{F}\end{array}$ & $\begin{array}{l}71 \\
59\end{array}$ & $\begin{array}{l}71 \\
58\end{array}$ & $\begin{array}{l}68 \\
57\end{array}$ & $\begin{array}{l}72 \\
59\end{array}$ & $\begin{array}{l}77 \\
64\end{array}$ & $\begin{array}{l}80 \\
68\end{array}$ & $\begin{array}{l}75 \\
66\end{array}$ & $\begin{array}{l}79 \\
67\end{array}$ & $\begin{array}{l}83 \\
67\end{array}$ \\
\hline $\mathbf{G}$ & $\begin{array}{l}\text { N. } \\
\text { F. }\end{array}$ & 73 & $\begin{array}{c}81 \\
\ldots\end{array}$ & $\begin{array}{l}82 \\
\ldots\end{array}$ & 87 & $\begin{array}{c}90 \\
\ldots\end{array}$ & 90 & $\begin{array}{l}90 \\
\ldots\end{array}$ & $\begin{array}{l}87 \\
\ldots\end{array}$ & $\begin{array}{l}94 \\
\ldots\end{array}$ \\
\hline $\mathbf{H}$ & $\begin{array}{l}\mathbf{N} . \\
\mathbf{F} .\end{array}$ & 71 & 76 & 78 & 79 & 81 & 83 & 82 & 86 & 90 \\
\hline
\end{tabular}

$1 \mathrm{~N}=\mathrm{No}$ segments frozen at center of fruit; $\mathrm{F}=$ one or more segments frozen at center of fruit. In either case, however, the fruits may or may not have been frozen in one or both ends.

2 Plot picked by mistake.

Not enough frozen fruit to insure significant results. 



Fig. 11.-Average yields of juice ( $\mathrm{ml}$. per fruit) from nonfrozen and frozen Valencia oranges.

(See table 5 for these and other values.)

amounts of juice were later determined on a volume basis, in the separator tests.

Total soluble solids. - There was a gradual increase in total soluble solids in the juice from both nonfrozen and frozen fruit until the latter part of the season (table 7 and fig. 13). The table gives the value for each determination for each plot, but the curves in Figure 13 show the trends for only four plots-those which furnished enough frozen fruits to give reliable results during the entire season. 
TABLE 6-Yields of Juice from Nonfrozen and Frozen Valencia Oranges (Per Cent of Weight of Fruit)

ALL FIGURES ARE PER CENT

\begin{tabular}{|c|c|c|c|c|c|c|c|c|c|c|}
\hline Plot & \multicolumn{2}{|c|}{$\begin{array}{l}\text { Condition } \\
\text { of fruit }\end{array}$} & $\begin{array}{l}\text { Feb. } \\
28\end{array}$ & $\underset{14}{\text { March }}$ & $\underset{28}{\operatorname{March}}$ & April & $\begin{array}{l}\text { April } \\
25\end{array}$ & $\underset{9}{\operatorname{May}}$ & $\underset{23}{\operatorname{May}}$ & $\underset{6}{\text { June }}$ \\
\hline $\mathbf{A}$ & & $\begin{array}{l}43 \\
34\end{array}$ & $\begin{array}{l}47 \\
39\end{array}$ & $\begin{array}{l}49 \\
42\end{array}$ & $\begin{array}{l}50 \\
45\end{array}$ & $\begin{array}{l}49 \\
45\end{array}$ & $\begin{array}{l}51 \\
45\end{array}$ & $\begin{array}{l}53 \\
47\end{array}$ & $\begin{array}{l}50 \\
43\end{array}$ \\
\hline B & \multicolumn{2}{|l|}{$\begin{array}{l}\text { N. } \\
\text { F. }\end{array}$} & $\begin{array}{l}43 \\
42\end{array}$ & $\begin{array}{l}46 \\
37\end{array}$ & $\begin{array}{l}47 \\
39\end{array}$ & $\begin{array}{l}48 \\
40\end{array}$ & $\begin{array}{l}49 \\
42\end{array}$ & $\begin{array}{l}51 \\
44\end{array}$ & $\begin{array}{l}51 \\
44\end{array}$ & $\begin{array}{l}50 \\
41\end{array}$ \\
\hline C & \multicolumn{2}{|l|}{$\begin{array}{l}\text { N. } \\
\text { F. }\end{array}$} & $\begin{array}{l}47 \\
37\end{array}$ & $\begin{array}{l}46 \\
38\end{array}$ & $\begin{array}{l}49 \\
40\end{array}$ & $\begin{array}{l}50 \\
39\end{array}$ & $\begin{array}{l}50 \\
.^{3}\end{array}$ & $\begin{array}{l}52 \\
\ldots\end{array}$ & $\begin{array}{l}50 \\
. .\end{array}$ & $\begin{array}{l}52 \\
\ldots\end{array}$ \\
\hline D & \multicolumn{2}{|l|}{$\begin{array}{l}\mathbf{N} . \\
\text { F. }\end{array}$} & $\begin{array}{l}43 \\
32\end{array}$ & $\begin{array}{l}38 \\
39\end{array}$ & $\begin{array}{l}46 \\
38\end{array}$ & $\begin{array}{l}47 \\
40\end{array}$ & $\begin{array}{l}47 \\
39\end{array}$ & $\begin{array}{l}48 \\
40\end{array}$ & $\begin{array}{l}50 \\
41\end{array}$ & $\begin{array}{l}48 \\
42\end{array}$ \\
\hline $\mathbf{E}$ & \multicolumn{2}{|l|}{$\begin{array}{l}\mathrm{N} \\
\mathrm{F}\end{array}$} & $\begin{array}{l}41 \\
36\end{array}$ & $\begin{array}{l}42 \\
36\end{array}$ & $\begin{array}{l}40 \\
37\end{array}$ & $\begin{array}{l}45 \\
39\end{array}$ & $\begin{array}{l}46 \\
40\end{array}$ & $\begin{array}{l}48 \\
38\end{array}$ & $\begin{array}{l}48 \\
41\end{array}$ & $\begin{array}{l}47 \\
39\end{array}$ \\
\hline$F$ & & $\begin{array}{l}49 \\
37\end{array}$ & $\begin{array}{l}53 \\
38\end{array}$ & $\begin{array}{l}50 \\
42\end{array}$ & $\begin{array}{l}51 \\
44\end{array}$ & $\begin{array}{l}52 \\
37\end{array}$ & $\begin{array}{l}52 \\
43\end{array}$ & $\begin{array}{l}53 \\
47\end{array}$ & $\begin{array}{l}52 \\
41\end{array}$ \\
\hline $\mathbf{G}$ & & $\begin{array}{l}40 \\
33\end{array}$ & $\begin{array}{l}44 \\
36\end{array}$ & $\begin{array}{l}46 \\
38\end{array}$ & $\begin{array}{l}47 \\
35\end{array}$ & $\begin{array}{l}45 \\
37\end{array}$ & $\begin{array}{l}48 \\
\ldots 3\end{array}$ & $\begin{array}{l}49 \\
\ldots\end{array}$ & $\begin{array}{l}48 \\
\cdots\end{array}$ \\
\hline $\mathbf{H}$ & \multicolumn{2}{|l|}{$\begin{array}{l}\text { N. } \\
\text { F. }\end{array}$} & $\begin{array}{l}41 \\
32\end{array}$ & $\begin{array}{l}44 \\
33\end{array}$ & $\begin{array}{l}53 \\
35\end{array}$ & $\begin{array}{l}47 \\
\ldots 3\end{array}$ & $\begin{array}{l}47 \\
\ldots\end{array}$ & $\begin{array}{l}48 \\
\ldots\end{array}$ & $\begin{array}{l}49 \\
\ldots\end{array}$ & $\begin{array}{l}50 \\
\ldots\end{array}$ \\
\hline Plot & $\begin{array}{l}\text { Condition } \\
\text { of fruit }\end{array}$ & $\underset{20}{\text { June }}$ & $\underset{5}{J u l y}$ & $\begin{array}{l}\text { July } \\
18\end{array}$ & August & $\underset{15}{\text { August }}$ & $\underset{29}{\text { August }}$ & Sept. & $\begin{array}{l}\text { Sept. } \\
26\end{array}$ & $\begin{array}{l}\text { Oct. } \\
10\end{array}$ \\
\hline $\mathbf{A}$ & $\begin{array}{l}\mathbf{N}^{1} \ldots \\
\mathbf{F}^{1} \ldots \ldots\end{array}$ & $\begin{array}{l}54 \\
48\end{array}$ & $\begin{array}{l}53 \\
46\end{array}$ & $\begin{array}{l}56 \\
49\end{array}$ & $\begin{array}{l}56 \\
48\end{array}$ & $\begin{array}{l}56 \\
49\end{array}$ & $\begin{array}{l}57 \\
47\end{array}$ & $\begin{array}{l}58 \\
51\end{array}$ & $\begin{array}{l}59 \\
50\end{array}$ & $\begin{array}{l}58 \\
54\end{array}$ \\
\hline B & $\begin{array}{l}\text { N. } \\
\text { F. }\end{array}$ & $\begin{array}{l}53 \\
43\end{array}$ & $\begin{array}{l}53 \\
46\end{array}$ & $\begin{array}{l}54 \\
47\end{array}$ & $\because^{2}$ & $\begin{array}{l}. \\
.\end{array}$ & $\begin{array}{l}. \\
\ldots\end{array}$ & . & . & $\begin{array}{l}. \\
.\end{array}$ \\
\hline C & $\begin{array}{l}\mathbf{N} \\
\mathbf{F}\end{array}$ & $\begin{array}{l}53 \\
\ldots\end{array}$ & $\begin{array}{l}55 \\
\ldots\end{array}$ & 56 & $\begin{array}{l}57 \\
. .\end{array}$ & 57 & $\begin{array}{l}58 \\
\ldots\end{array}$ & $\begin{array}{l}58 \\
\ldots\end{array}$ & $\begin{array}{l}58 \\
\ldots\end{array}$ & $\begin{array}{l}59 \\
\ldots\end{array}$ \\
\hline D & $\begin{array}{l}\text { N. } \\
\text { F. }\end{array}$ & $\begin{array}{l}54 \\
42\end{array}$ & $\begin{array}{l}53 \\
46\end{array}$ & $\begin{array}{l}53 \\
49\end{array}$ & $\begin{array}{l}54 \\
49\end{array}$ & $\begin{array}{l}55 \\
46\end{array}$ & $\begin{array}{l}55 \\
50\end{array}$ & $\begin{array}{l}55 \\
49\end{array}$ & $\begin{array}{l}59 \\
51\end{array}$ & $\begin{array}{l}56 \\
46\end{array}$ \\
\hline $\mathbf{E}$ & $\begin{array}{l}\mathrm{N} \\
\mathrm{F}\end{array}$ & $\begin{array}{l}45 \\
43\end{array}$ & $\begin{array}{l}50 \\
47\end{array}$ & $\begin{array}{l}52 \\
44\end{array}$ & $\begin{array}{l}52 \\
45\end{array}$ & $\begin{array}{l}53 \\
43\end{array}$ & $\begin{array}{l}54 \\
47\end{array}$ & $\begin{array}{l}53 \\
48\end{array}$ & $\begin{array}{l}54 \\
48\end{array}$ & $\begin{array}{l}53 \\
48\end{array}$ \\
\hline $\mathbf{F}$ & $\begin{array}{l}\text { N. } \\
\text { F. }\end{array}$ & $\begin{array}{l}54 \\
51\end{array}$ & $\begin{array}{l}55 \\
44\end{array}$ & $\begin{array}{l}56 \\
47\end{array}$ & $\begin{array}{l}57 \\
46\end{array}$ & $\begin{array}{l}54 \\
51\end{array}$ & $\begin{array}{l}59 \\
48\end{array}$ & $\begin{array}{l}64 \\
53\end{array}$ & $\begin{array}{l}59 \\
52\end{array}$ & $\begin{array}{l}60 \\
48\end{array}$ \\
\hline G & $\begin{array}{l}\mathrm{N} \ldots \\
\mathrm{F} \ldots\end{array}$ & $\begin{array}{l}53 \\
\ldots\end{array}$ & $\begin{array}{l}52 \\
\ldots\end{array}$ & $\begin{array}{l}54 \\
\ldots\end{array}$ & $\begin{array}{l}55 \\
\ldots\end{array}$ & $\begin{array}{l}55 \\
\ldots\end{array}$ & $\begin{array}{l}57 \\
\ldots\end{array}$ & $\begin{array}{l}57 \\
\ldots\end{array}$ & $\begin{array}{l}57 \\
\ldots\end{array}$ & $\begin{array}{l}59 \\
\ldots\end{array}$ \\
\hline $\mathbf{H}$ & $\begin{array}{l}\text { N. } \\
\text { F. }\end{array}$ & 51 & 53 & 59 & $\begin{array}{l}55 \\
\ldots\end{array}$ & 56 & $\begin{array}{l}55 \\
\ldots\end{array}$ & $\begin{array}{l}55 \\
\cdots\end{array}$ & 58 & 57 \\
\hline
\end{tabular}

${ }^{1} \mathrm{~N}=$ No segments frozen at center of fruit; $\mathrm{F}=$ one or more segments frozen at center of fruit. In either case, however, the fruits may or may not have been frozen in one or both ends.

2 Plot picked by mistake.

3 Not enough frozen fruit to insure significant results. 

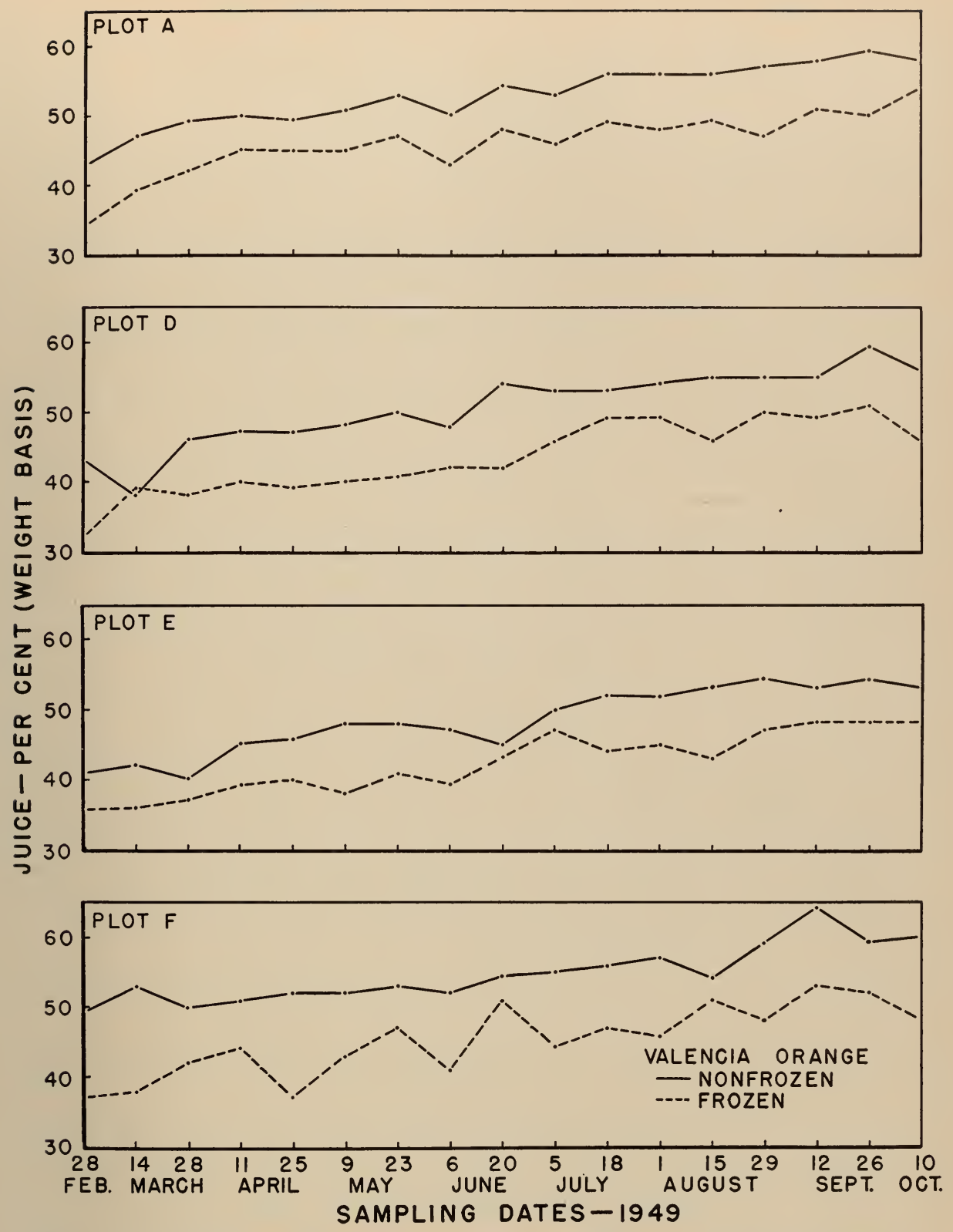

Fig. 12.-Average yields of juice (wt. basis) from nonfrozen and frozen Valencia oranges. (See table 6 for these and other values.)

Figure 13 shows that the spread between the values for nonfrozen and frozen fruits was greatest for Plot A, and smallest for Plot E. No definite reason for this difference in spread can be given, but the following is a possible explanation.
Table 1 shows that the total percentage of frozen fruits from the two plots was approximately the same, but Table 4 shows that, while the total numbers of frozen segments in the stem end and center were about the same, the number frozen in the 
TABLE 7-Total Soluble Solids in Juice of Nonfrozen and Frozen Valencia Oranges

ALL FIGURES ARE PER CENT

\begin{tabular}{|c|c|c|c|c|c|c|c|c|c|c|}
\hline Plot & \multicolumn{2}{|c|}{$\begin{array}{l}\text { Condition } \\
\text { of fruit }\end{array}$} & $\begin{array}{c}\text { Feb. } \\
28\end{array}$ & $\underset{14}{\operatorname{March}}$ & $\underset{28}{\operatorname{March}}$ & April & April & $\underset{9}{\operatorname{May}}$ & $\underset{23}{\operatorname{May}}$ & $\underset{6}{J u n e}$ \\
\hline A & \multicolumn{2}{|c|}{$\begin{array}{l}\mathbf{N}^{1} \ldots \ldots \ldots \ldots \ldots \ldots \\
\mathbf{F}^{1} \ldots \ldots \ldots \ldots \ldots\end{array}$} & $\begin{array}{l}9.11 \\
9.01\end{array}$ & $\begin{array}{l}9.11 \\
8.57\end{array}$ & $\begin{array}{l}9.91 \\
9.06\end{array}$ & $\begin{array}{r}10.11 \\
9.37\end{array}$ & $\begin{array}{l}9.71 \\
9.37\end{array}$ & $\begin{array}{r}10.83 \\
9.23\end{array}$ & $\begin{array}{r}10.63 \\
9.23\end{array}$ & $\begin{array}{r}11.03 \\
9.57\end{array}$ \\
\hline B & \multicolumn{2}{|c|}{$\begin{array}{l}\mathbf{N} \ldots \ldots \ldots \ldots \ldots \\
\mathrm{F} \ldots \ldots \ldots \ldots \ldots\end{array}$} & $\begin{array}{l}9.91 \\
9.91\end{array}$ & $\begin{array}{l}9.91 \\
9.83\end{array}$ & $\begin{array}{r}10.23 \\
9.91\end{array}$ & $\begin{array}{l}10.43 \\
10.23\end{array}$ & $\begin{array}{l}10.57 \\
10.57\end{array}$ & $\begin{array}{l}11.31 \\
10.57\end{array}$ & $\begin{array}{l}11.03 \\
10.31\end{array}$ & $\begin{array}{l}11.11 \\
10.63\end{array}$ \\
\hline C & \multicolumn{2}{|c|}{$\begin{array}{l}\mathbf{N} \ldots \ldots \ldots \ldots \ldots \\
\mathbf{F} \ldots \ldots \ldots \ldots\end{array}$} & $\begin{array}{l}9.83 \\
9.74\end{array}$ & $\begin{array}{l}9.71 \\
9.63\end{array}$ & $\begin{array}{l}9.91 \\
9.31\end{array}$ & $\begin{array}{r}10.03 \\
9.43\end{array}$ & $\begin{array}{l}10.57 \\
\ldots .{ }^{3}\end{array}$ & $\begin{array}{l}9.97 \\
\ldots\end{array}$ & $\begin{array}{l}9.97 \\
\ldots\end{array}$ & $\begin{array}{r}10.57 \\
\ldots\end{array}$ \\
\hline D & \multicolumn{2}{|c|}{$\begin{array}{l}\mathbf{N} \ldots \ldots \ldots \ldots \ldots \\
\mathbf{F} \ldots \ldots \ldots \ldots \ldots\end{array}$} & $\begin{array}{l}9.71 \\
9.23\end{array}$ & $\begin{array}{l}9.57 \\
9.23\end{array}$ & $\begin{array}{l}9.71 \\
9.23\end{array}$ & $\begin{array}{l}9.77 \\
9.11\end{array}$ & $\begin{array}{l}9.71 \\
8.83\end{array}$ & $\begin{array}{r}10.17 \\
9.11\end{array}$ & $\begin{array}{l}9.43 \\
8.63\end{array}$ & $\begin{array}{l}9.71 \\
9.11\end{array}$ \\
\hline $\mathrm{E}$ & \multicolumn{2}{|c|}{$\begin{array}{l}\mathbf{N} \ldots \ldots \ldots \ldots \ldots \\
\mathbf{F} \ldots \ldots \ldots \ldots \ldots\end{array}$} & $\begin{array}{l}9.23 \\
9.23\end{array}$ & $\begin{array}{l}8.91 \\
8.63\end{array}$ & $\begin{array}{l}9.71 \\
9.51\end{array}$ & $\begin{array}{l}9.91 \\
9.57\end{array}$ & $\begin{array}{r}10.43 \\
9.91\end{array}$ & $\begin{array}{r}10.57 \\
9.77\end{array}$ & $\begin{array}{r}10.17 \\
9.71\end{array}$ & $\begin{array}{r}10.57 \\
9.91\end{array}$ \\
\hline $\mathrm{F}$ & \multicolumn{2}{|c|}{$\begin{array}{l}\mathbf{N} \ldots \ldots \ldots \ldots \ldots \\
\mathbf{F} \ldots \ldots \ldots \ldots \ldots\end{array}$} & $\begin{array}{l}8.91 \\
8.73\end{array}$ & $\begin{array}{l}9.71 \\
9.17\end{array}$ & $\begin{array}{l}9.23 \\
8.63\end{array}$ & $\begin{array}{l}9.83 \\
9.11\end{array}$ & $\begin{array}{l}9.97 \\
9.11\end{array}$ & $\begin{array}{r}10.31 \\
9.23\end{array}$ & $\begin{array}{r}10.03 \\
9.37\end{array}$ & $\begin{array}{r}10.57 \\
9.51\end{array}$ \\
\hline $\mathbf{G}$ & \multicolumn{2}{|c|}{$\begin{array}{l}\mathrm{N} \ldots \ldots \ldots \ldots \ldots \\
\mathrm{F} \ldots \ldots \ldots \ldots \ldots \ldots\end{array}$} & $\begin{array}{l}10.91 \\
10.68\end{array}$ & $\begin{array}{l}10.57 \\
10.41\end{array}$ & $\begin{array}{r}9.71 \\
10.63\end{array}$ & $\begin{array}{l}10.43 \\
10.11\end{array}$ & $\begin{array}{l}10.37 \\
10.21\end{array}$ & $\begin{array}{c}10.57 \\
\ldots{ }^{3}\end{array}$ & $\begin{array}{l}9.91 \\
\ldots\end{array}$ & $\begin{array}{c}10.03 \\
\ldots\end{array}$ \\
\hline $\mathbf{H}$ & \multicolumn{2}{|c|}{$\begin{array}{l}\mathbf{N} \ldots \ldots \ldots \ldots \ldots \\
\mathbf{F} \ldots \ldots \ldots \ldots \ldots\end{array}$} & $\begin{array}{l}10.17 \\
10.01\end{array}$ & $\begin{array}{r}10.03 \\
9.57\end{array}$ & $\begin{array}{r}10.17 \\
9.91\end{array}$ & $\begin{array}{c}10.17 \\
\ldots{ }^{3}\end{array}$ & $\begin{array}{c}10.17 \\
\ldots\end{array}$ & 10.23 & $\begin{array}{c}10.03 \\
\ldots\end{array}$ & $\begin{array}{c}10.11 \\
\ldots\end{array}$ \\
\hline Plot & $\begin{array}{l}\text { Condition } \\
\text { of fruit }\end{array}$ & $\underset{20}{\text { June }}$ & July & $\begin{array}{c}\text { July } \\
18\end{array}$ & $\underset{1}{\text { August }}$ & $\underset{15}{\text { August }}$ & $\underset{29}{\text { August }}$ & $\begin{array}{l}\text { Sept. } \\
12\end{array}$ & $\begin{array}{l}\text { Sept. } \\
26\end{array}$ & Oct. \\
\hline A & $\begin{array}{l}\mathrm{N}^{1} . \\
\mathrm{F}^{1} .\end{array}$ & $\begin{array}{r}11.23 \\
9.77\end{array}$ & $\begin{array}{l}11.91 \\
10.23\end{array}$ & $\begin{array}{r}11.43 \\
9.91\end{array}$ & $\begin{array}{l}11.96 \\
10.57\end{array}$ & $\begin{array}{l}11.91 \\
10.57\end{array}$ & $\begin{array}{r}11.71 \\
9.31\end{array}$ & $\begin{array}{l}11.57 \\
10.11\end{array}$ & $\begin{array}{r}11.57 \\
9.71\end{array}$ & $\begin{array}{r}11.77 \\
9.91\end{array}$ \\
\hline B & $\begin{array}{l}\text { N.. } \\
\text { F. . }\end{array}$ & $\begin{array}{l}11.23 \\
11.03\end{array}$ & $\begin{array}{l}11.71 \\
11.31\end{array}$ & $\begin{array}{l}12.01 \\
11.91\end{array}$ & $\ldots{ }^{2}$ & & $\begin{array}{l}\cdots \\
\cdots\end{array}$ & $\begin{array}{l}\cdots \\
\cdots\end{array}$ & $\begin{array}{l}\cdots \\
\cdots\end{array}$ & $\begin{array}{l}\cdots \\
\cdots\end{array}$ \\
\hline C & $\begin{array}{l}\text { N. } \\
\text { F. }\end{array}$ & $\begin{array}{c}10.77 \\
\ldots \ldots\end{array}$ & $\begin{array}{c}11.23 \\
\ldots\end{array}$ & $\begin{array}{c}11.37 \\
\ldots\end{array}$ & 11.57 & $\begin{array}{c}12.01 \\
\ldots\end{array}$ & $\begin{array}{c}11.91 \\
\ldots\end{array}$ & $\begin{array}{c}11.91 \\
\ldots\end{array}$ & $\begin{array}{c}12.01 \\
\ldots\end{array}$ & $\begin{array}{c}11.96 \\
\ldots\end{array}$ \\
\hline D & $\begin{array}{l}\text { N. } \\
\text { F. }\end{array}$ & $\begin{array}{l}9.83 \\
9.11\end{array}$ & $\begin{array}{l}9.97 \\
9.11\end{array}$ & $\begin{array}{r}10.57 \\
9.31\end{array}$ & $\begin{array}{r}10.37 \\
9.71\end{array}$ & $\begin{array}{r}10.71 \\
9.63\end{array}$ & $\begin{array}{r}10.51 \\
9.51\end{array}$ & $\begin{array}{r}10.57 \\
9.51\end{array}$ & $\begin{array}{r}10.57 \\
9.43\end{array}$ & $\begin{array}{r}10.37 \\
9.23\end{array}$ \\
\hline $\mathrm{E}$ & $\begin{array}{l}\text { N. } \\
\text { F. }\end{array}$ & $\begin{array}{l}11.03 \\
10.43\end{array}$ & $\begin{array}{l}11.23 \\
10.57\end{array}$ & $\begin{array}{l}11.51 \\
10.83\end{array}$ & $\begin{array}{l}11.51 \\
10.97\end{array}$ & $\begin{array}{l}11.63 \\
10.97\end{array}$ & $\begin{array}{l}11.23 \\
10.37\end{array}$ & $\begin{array}{l}11.20 \\
10.43\end{array}$ & $\begin{array}{l}11.17 \\
10.37\end{array}$ & $\begin{array}{r}10.83 \\
9.43\end{array}$ \\
\hline$F$ & $\begin{array}{l}\text { N. } \\
\text { F. }\end{array}$ & $\begin{array}{l}10.63 \\
10.17\end{array}$ & $\begin{array}{l}11.03 \\
10.23\end{array}$ & $\begin{array}{r}11.37 \\
9.97\end{array}$ & $\begin{array}{l}11.51 \\
10.57\end{array}$ & $\begin{array}{l}11.43 \\
10.31\end{array}$ & $\begin{array}{l}11.23 \\
10.63\end{array}$ & $\begin{array}{l}10.63 \\
10.77\end{array}$ & $\begin{array}{l}11.23 \\
10.57\end{array}$ & $\begin{array}{r}10.97 \\
9.06\end{array}$ \\
\hline G & $\begin{array}{l}\text { N. } \\
\text { F. }\end{array}$ & $\begin{array}{c}10.23 \\
\ldots .\end{array}$ & 10.51 & $\begin{array}{r}10.57 \\
\ldots\end{array}$ & $\begin{array}{c}11.03 \\
\ldots \ldots\end{array}$ & 11.11 & $\begin{array}{c}11.23 \\
\ldots\end{array}$ & $\begin{array}{c}11.37 \\
\ldots\end{array}$ & $\begin{array}{c}11.23 \\
\ldots \ldots\end{array}$ & $\begin{array}{r}11.23 \\
\ldots .\end{array}$ \\
\hline $\mathbf{H}$ & $\begin{array}{l}\mathrm{N} . \\
\mathrm{F} .\end{array}$ & 10.37 & 10.57 & 10.57 & 10.97 & 10.97 & $\begin{array}{c}11.11 \\
\ldots\end{array}$ & $\begin{array}{c}11.03 \\
\ldots\end{array}$ & $\begin{array}{c}11.03 \\
\ldots\end{array}$ & $\begin{array}{r}11.17 \\
\ldots .\end{array}$ \\
\hline
\end{tabular}

$1 \mathrm{~N}=\mathrm{No}$ segments frozen at center of fruit; $\mathrm{F}=$ one or more segments frozen at center of fruit. In either case, however, the fruits may or may not have been frozen in one or both ends.

2 Plot picked by mistake.

${ }^{3}$ Not enough frozen fruit to insure significant results. 

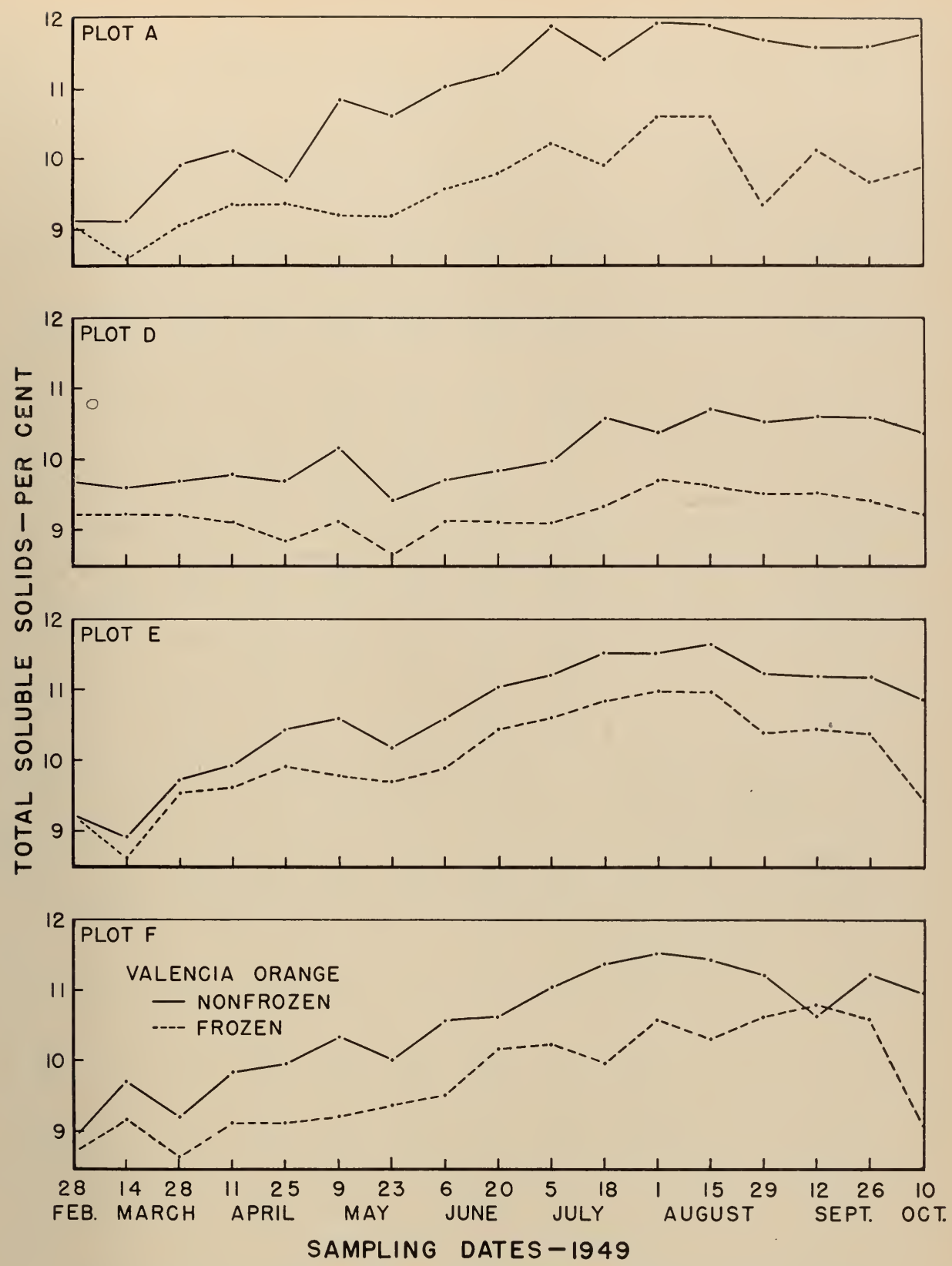

Fig. 13.-Total soluble solids in the juice of nonfrozen and frozen Valencia oranges.

(See table 7 for these and other values.) 
TABLE 8-Concentrations of Free Acids (as Citric) in Nonfrozen and Frozen Valencia Oranges

ALL FIGURES ARE PER CENT

\begin{tabular}{|c|c|c|c|c|c|c|c|c|c|c|}
\hline Plot & \multicolumn{2}{|c|}{$\begin{array}{l}\text { Condition } \\
\text { of fruit }\end{array}$} & $\begin{array}{c}\text { Feb. } \\
28\end{array}$ & $\underset{14}{\text { March }}$ & $\underset{28}{\text { March }}$ & April & $\underset{25}{\text { April }}$ & $\underset{9}{\operatorname{May}}$ & $\underset{23}{\text { May }}$ & $\underset{6}{\operatorname{Jun} \theta}$ \\
\hline A & & $\begin{array}{l}2.04 \\
2.01\end{array}$ & $\begin{array}{l}1.86 \\
1.80\end{array}$ & $\begin{array}{l}1.79 \\
1.58\end{array}$ & $\begin{array}{l}1.57 \\
1.39\end{array}$ & $\begin{array}{l}1.16 \\
1.04\end{array}$ & $\begin{array}{l}1.37 \\
1.19\end{array}$ & $\begin{array}{l}1.34 \\
1.17\end{array}$ & $\begin{array}{l}1.23 \\
1.15\end{array}$ \\
\hline B & & $\begin{array}{l}2.15 \\
2.15\end{array}$ & $\begin{array}{l}1.94 \\
1.91\end{array}$ & $\begin{array}{l}1.84 \\
1.77\end{array}$ & $\begin{array}{l}1.58 \\
1.47\end{array}$ & $\begin{array}{l}1.24 \\
1.23\end{array}$ & $\begin{array}{l}1.41 \\
1.36\end{array}$ & $\begin{array}{l}1.45 \\
1.35\end{array}$ & $\begin{array}{l}1.30 \\
1.28\end{array}$ \\
\hline C & \multicolumn{2}{|l|}{$\begin{array}{l}\mathbf{N} . \\
\text { F. }\end{array}$} & $\begin{array}{l}2.06 \\
2.02\end{array}$ & $\begin{array}{l}2.16 \\
2.16\end{array}$ & $\begin{array}{l}1.93 \\
1.72\end{array}$ & $\begin{array}{l}1.72 \\
1.46\end{array}$ & $\begin{array}{l}1.30 \\
\ldots .^{3}\end{array}$ & 1.46 & 1.43 & $\begin{array}{l}1.39 \\
\ldots \ldots\end{array}$ \\
\hline D & \multicolumn{2}{|l|}{$\begin{array}{l}\text { N. } \\
\text { F. }\end{array}$} & $\begin{array}{l}2.17 \\
2.06\end{array}$ & $\begin{array}{l}1.99 \\
1.98\end{array}$ & $\begin{array}{l}1.75 \\
1.65\end{array}$ & $\begin{array}{l}1.49 \\
1.36\end{array}$ & $\begin{array}{l}1.15 \\
1.10\end{array}$ & $\begin{array}{l}1.31 \\
1.25\end{array}$ & $\begin{array}{l}1.25 \\
1.18\end{array}$ & $\begin{array}{l}1.21 \\
1.17\end{array}$ \\
\hline $\mathbf{E}$ & \multicolumn{2}{|c|}{$\begin{array}{l}\mathbf{N} \ldots \ldots \ldots \ldots \ldots \ldots \ldots \ldots \ldots \ldots \ldots \ldots \\
\mathbf{F} \ldots \ldots \ldots \ldots \ldots\end{array}$} & $\begin{array}{l}2.13 \\
2.01\end{array}$ & $\begin{array}{l}1.95 \\
1.82\end{array}$ & $\begin{array}{l}1.82 \\
1.65\end{array}$ & $\begin{array}{l}1.52 \\
1.34\end{array}$ & $\begin{array}{l}1.21 \\
1.14\end{array}$ & $\begin{array}{l}1.39 \\
1.27\end{array}$ & $\begin{array}{l}1.30 \\
1.24\end{array}$ & $\begin{array}{l}1.29 \\
1.19\end{array}$ \\
\hline $\mathbf{F}$ & \multicolumn{2}{|l|}{$\begin{array}{l}\text { N. } \\
\text { F. }\end{array}$} & $\begin{array}{l}1.98 \\
1.93\end{array}$ & $\begin{array}{l}1.70 \\
1.67\end{array}$ & $\begin{array}{l}1.55 \\
1.40\end{array}$ & $\begin{array}{l}1.38 \\
1.30\end{array}$ & $\begin{array}{l}1.12 \\
1.05\end{array}$ & $\begin{array}{l}1.23 \\
1.14\end{array}$ & $\begin{array}{l}1.23 \\
1.16\end{array}$ & $\begin{array}{l}1.20 \\
1.11\end{array}$ \\
\hline G & \multicolumn{2}{|l|}{$\begin{array}{l}\text { N. } \\
\text { F. }\end{array}$} & $\begin{array}{l}2.57 \\
2.45\end{array}$ & $\begin{array}{l}2.26 \\
2.19\end{array}$ & $\begin{array}{l}1.93 \\
1.87\end{array}$ & $\begin{array}{l}1.76 \\
1.70\end{array}$ & $\begin{array}{l}1.43 \\
1.35\end{array}$ & 1.63 & 1.52 & 1.46 \\
\hline $\mathbf{H}$ & \multicolumn{2}{|l|}{$\begin{array}{l}\text { N. } \\
\text { F. . }\end{array}$} & $\begin{array}{l}2.49 \\
2.40\end{array}$ & $\begin{array}{l}2.17 \\
2.00\end{array}$ & $\begin{array}{l}2.07 \\
2.07\end{array}$ & $\begin{array}{l}1.73 \\
\ldots .{ }^{3}\end{array}$ & $\begin{array}{l}1.40 \\
\ldots \ldots\end{array}$ & $\begin{array}{l}1.55 \\
\ldots \ldots\end{array}$ & $\begin{array}{l}1.55 \\
\ldots \ldots\end{array}$ & $\begin{array}{l}1.32 \\
\ldots \ldots\end{array}$ \\
\hline Plot & $\begin{array}{l}\text { Condition } \\
\text { of fruit }\end{array}$ & $\underset{20}{\text { June }}$ & July & $\begin{array}{c}\text { July } \\
18\end{array}$ & $\underset{1}{\text { August }}$ & ${ }_{15}^{\text {August }}$ & August & $\begin{array}{l}\text { Sept. } \\
12\end{array}$ & $\begin{array}{l}\text { Sept. } \\
26\end{array}$ & $\begin{array}{l}\text { Oct. } \\
10\end{array}$ \\
\hline $\mathbf{A}$ & $\begin{array}{l}\mathrm{N}^{1} . \\
\mathrm{F}^{1} . .\end{array}$ & $\begin{array}{l}1.23 \\
1.10\end{array}$ & $\begin{array}{l}1.20 \\
1.15\end{array}$ & $\begin{array}{l}1.21 \\
1.16\end{array}$ & $\begin{array}{l}1.22 \\
1.22\end{array}$ & $\begin{array}{l}1.23 \\
1.20\end{array}$ & $\begin{array}{l}1.23 \\
1.10\end{array}$ & $\begin{array}{l}1.07 \\
1.05\end{array}$ & $\begin{array}{l}1.07 \\
1.02\end{array}$ & $\begin{array}{l}1.10 \\
1.08\end{array}$ \\
\hline B & $\begin{array}{l}\text { N. } \\
\text { F. }\end{array}$ & $\begin{array}{l}1.19 \\
1.21\end{array}$ & $\begin{array}{l}1.25 \\
1.24\end{array}$ & $\begin{array}{l}1.27 \\
1.21\end{array}$ & $\ldots{ }^{2}$ & & $\ldots$ & & & $\ldots$ \\
\hline C & $\begin{array}{l}\text { N. . } \\
\text { F. . }\end{array}$ & 1.33 & 1.26 & 1.31 & 1.24 & 1.30 & $\begin{array}{l}1.26 \\
\ldots \ldots\end{array}$ & 1.25 & $\begin{array}{l}1.22 \\
\ldots .\end{array}$ & $\begin{array}{l}1.25 \\
\ldots \ldots\end{array}$ \\
\hline D & $\begin{array}{l}\mathrm{N} \\
\mathrm{F}\end{array}$ & $\begin{array}{l}1.11 \\
1.10\end{array}$ & $\begin{array}{l}1.10 \\
1.09\end{array}$ & $\begin{array}{l}1.12 \\
1.06\end{array}$ & $\begin{array}{l}1.10 \\
1.04\end{array}$ & $\begin{array}{l}1.12 \\
1.16\end{array}$ & $\begin{array}{l}1.07 \\
1.09\end{array}$ & $\begin{array}{l}1.10 \\
1.03\end{array}$ & $\begin{array}{l}1.09 \\
1.01\end{array}$ & $\begin{array}{l}1.08 \\
1.02\end{array}$ \\
\hline $\mathrm{E}$ & $\begin{array}{l}\text { N. } \\
\text { F. }\end{array}$ & $\begin{array}{l}1.27 \\
1.19\end{array}$ & $\begin{array}{l}1.26 \\
1.18\end{array}$ & $\begin{array}{l}1.23 \\
1.17\end{array}$ & $\begin{array}{l}1.22 \\
1.21\end{array}$ & $\begin{array}{l}1.19 \\
1.20\end{array}$ & $\begin{array}{l}1.14 \\
1.06\end{array}$ & $\begin{array}{l}1.09 \\
1.08\end{array}$ & $\begin{array}{l}1.09 \\
1.11\end{array}$ & $\begin{array}{l}1.09 \\
1.04\end{array}$ \\
\hline $\mathbf{F}$ & $\begin{array}{l}\text { N. } \\
\text { F. }\end{array}$ & $\begin{array}{l}1.19 \\
1.17\end{array}$ & $\begin{array}{l}1.19 \\
1.16\end{array}$ & $\begin{array}{l}1.21 \\
1.11\end{array}$ & $\begin{array}{l}1.19 \\
1.20\end{array}$ & $\begin{array}{l}1.24 \\
1.21\end{array}$ & $\begin{array}{l}1.17 \\
1.18\end{array}$ & $\begin{array}{l}1.11 \\
1.16\end{array}$ & $\begin{array}{l}1.05 \\
1.07\end{array}$ & $\begin{array}{l}1.10 \\
1.06\end{array}$ \\
\hline G & $\begin{array}{l}\mathrm{N} . \\
\mathrm{F} .\end{array}$ & 1.38 & 1.33 & 1.31 & 1.36 & 1.39 & 1.31 & 1.30 & 1.36 & 1.35 \\
\hline $\mathbf{H}$ & $\begin{array}{l}\mathrm{N} . \\
\mathrm{F} .\end{array}$ & 1.35 & $\begin{array}{l}1.27 \\
\cdots\end{array}$ & 1.29 & 1.31 & 1.31 & $\begin{array}{l}1.29 \\
\cdots\end{array}$ & 1.23 & $\begin{array}{l}1.20 \\
\cdots\end{array}$ & $\begin{array}{l}1.27 \\
\cdots\end{array}$ \\
\hline
\end{tabular}

${ }^{1} \mathrm{~N}=$ No segments frozen at center of fruit; $\mathrm{F}=$ one or more segments frozen at center of fruit. In either case, however, the fruits may or may not have been frozen in one or both ends.

${ }_{2}$ Plot picked by mistake.

3 Not enough frozen fruit to insure significant results. 

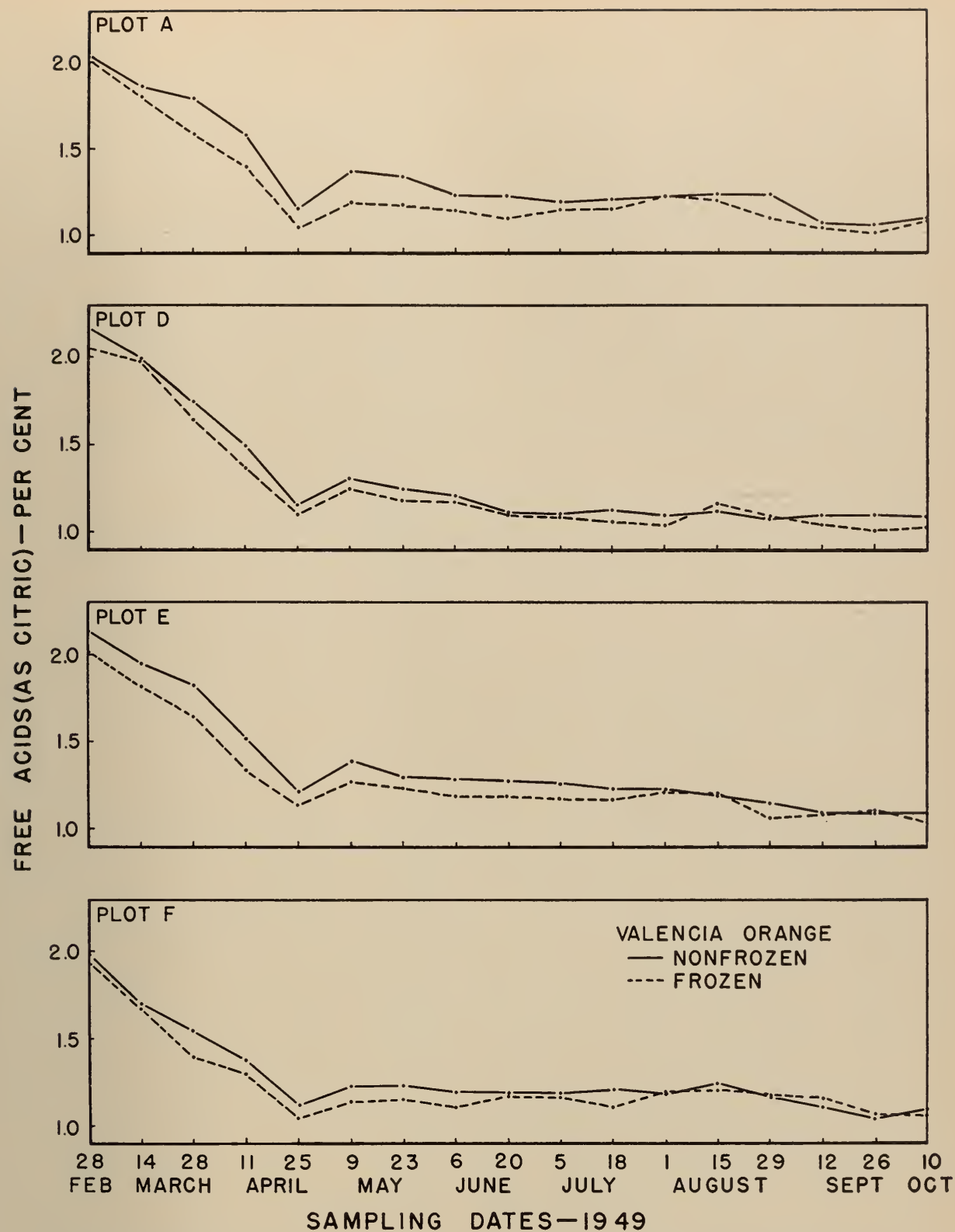

Fig. 14.-Free acids (as citric) in the juice from nonfrozen and frozen Valencia oranges.

(See table 8 for these and other values.)

stylar end was much greater for Plot A (645) than for Plot E (331). The concentration of soluble solids is normally greater in the stylar end than in any other portion of the mature and nearly mature Valencia orange. At the time these fruits were frozen (December or early January), they were so young that the concentration of soluble solids in the stylar end was about the same as, or even less than, that in other portions of the fruit. The greater injury, however, in this por- 
tion of the fruits from Plot A may have prevented the usual excessive accumulation of soluble solids in the stylar ends as the fruits matured.

Plot F (fig. 13) shows one instance in which the concentration of soluble solids was higher in the frozen fruits than in the nonfrozen. In Plot D, the concentration of soluble solids in the frozen fruits on February 28 was exactly the same as on October $10 \quad$ (9.23 per cent). Table 7 shows a similar trend in the nonfrozen fruits from Plot G. The concentration (11.23 per cent) on the last sampling date was only slightly higher than on the first sampling date (10.91 per cent). As Tables 5 and 6 show that the amount and per cent of juice increased, Table 7 and Figure 13 continue the evidence that there was a general tendency for the frozen fruits to recover.

Free acids (as citric).-As a rule, the differences between the total amounts of free acids in the nonfrozen and frozen fruits were not so great as those between the amounts of soluble solids. For example, in Plot A, on August 29, the concentration of soluble solids in the nonfrozen fruits was 26 per cent higher than that in the frozen fruits (table 7, fig. 13), while in Plot E, on April 11, the concentration of acids in the nonfrozen fruits was only 13 per cent higher than that in the frozen ones (table 8, fig. 14). These two examples are the extremes for soluble solids and acids for all plots. Table 8 and Figure 14 show not only that the fluctuations in amounts of acids were small, but also that there was relatively little decrease in the per cent of acids in the juice from both nonfrozen and frozen fruits after April 25. The table and the figure also show that, for some of the plots, the free acids were lower on April 25 than they were for several weeks or even months later. To illustrate: The acid values for the juice from nonfrozen fruits from Plots $A$ and $F$ were lower on April 25 than they were on any of the following dates until September 12. On a few dates in the latter part of the season, the amounts of acids in the frozen fruits exceeded those in the nonfrozen, as indicated by the crossing of the curves, in Figure 14.

Sugars.-The trends for the total sugars (table 9 and figs. 15 and 16) were similar to those for soluble solids. Such a similarity would be expected since approximately 85 per cent of the total soluble solids is composed of sugars-at least in fruits that are mature or nearly mature. There were fluctuations but, in general, the percentage of total sugars in the juice increased from the time of the first tests, on February 28, until the first or middle of August when it began to decrease in both the nonfrozen and frozen fruits. While the total sugars were less in the frozen fruits than in the nonfrozen, their increase was similar as the season advanced. Table 9 also shows that the trends for the concentrations of total sugars in the nonfrozen fruits from Plots $\mathrm{B}, \mathrm{C}, \mathrm{G}$, and $\mathrm{H}$ were similar to those shown in Figure 15 for the nonfrozen fruits from Plots A, D, E, and F.

The concentrations of reducing sugars remained approximately constant, or even decreased, from February 28 until early June in the four plots represented in Figure 16. This was especially true for the frozen fruits. The same may be said of the reducing sugars from the nonfrozen and frozen fruits from Plot B and the nonfrozen fruits from Plots C, G, and H (table 9).

The sucrose values were usually at a maximum from early May until September when, in some cases, they decreased. The ratio of reducing sugars to sucrose was highest in the first few tests and, in some instances, in the last two or three tests.

The general trends shown for the sugar and also for the soluble solids are, no doubt, closely related to the physiological changes which occurred in the fruits as 
TABLE 9-Sugars in Juice of Nonfrozen and Frozen Valencia Oranges ALL FIGURES ARE PER CENT

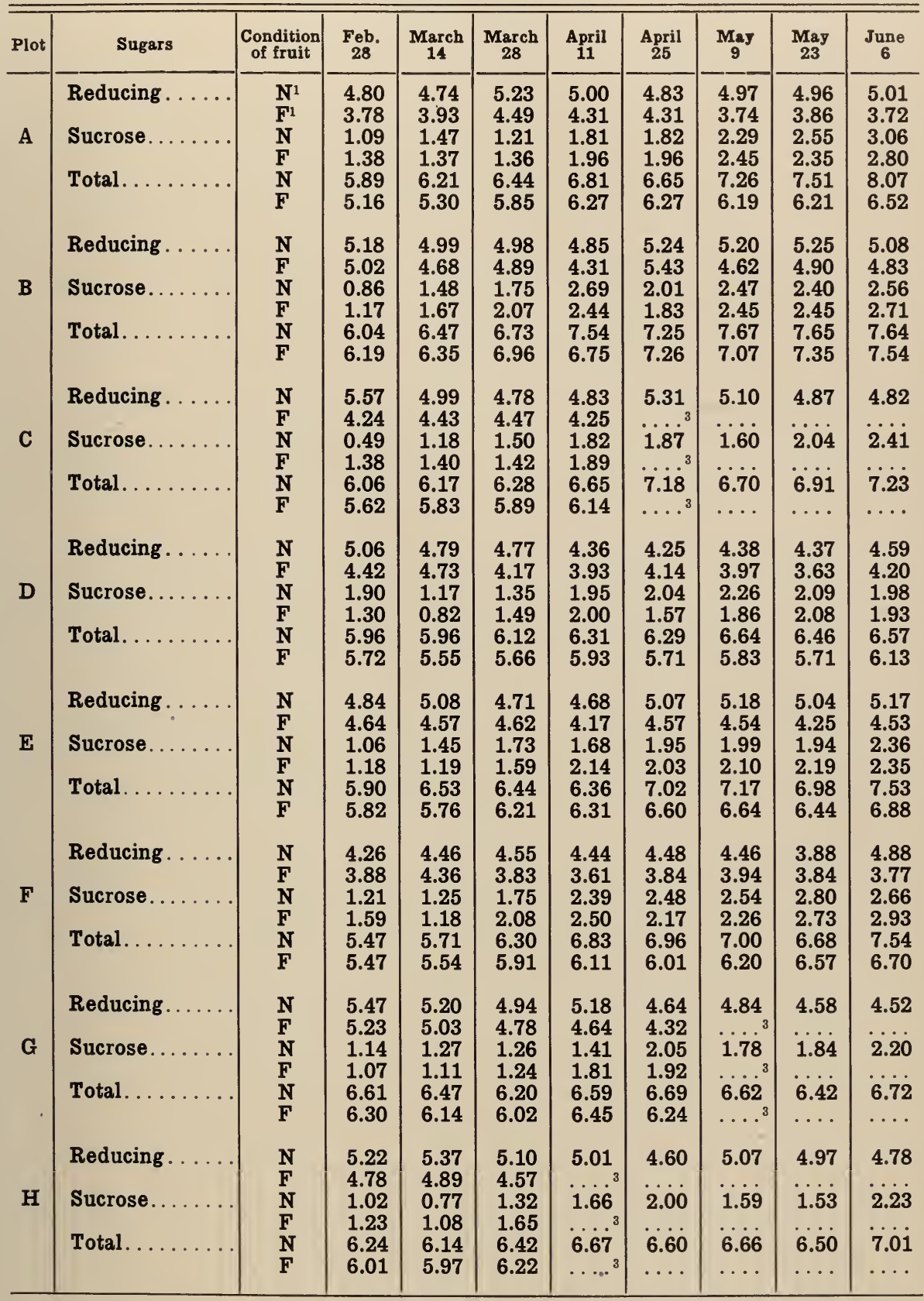

$1 \mathrm{~N}=$ No segments frozen at center of fruit; $\mathbf{F}=$ one or more segments frozen at center of fruit. In either case, however, the fruits may or may not have been frozen in one or both ends.

2 Plot picked by mistake.
3 Not enough frozen fruit to insure significant results. 
TABLE 9 (Continued)-Sugars in Juice of Nonfrozen and

Frozen Valencia Oranges

ALL FIGURES ARE PER CENT

\begin{tabular}{|c|c|c|c|c|c|c|c|c|c|c|c|}
\hline Plot & Sugars & $\begin{array}{c}\text { Condition } \\
\text { of fruit }\end{array}$ & $\underset{20}{\text { June }}$ & $\underset{5}{J_{u}}$ & $\begin{array}{l}\text { July }_{18} \\
\text {. }\end{array}$ & $\underset{1}{\text { August }}$ & $\underset{15}{\text { August }}$ & $\underset{29}{\text { August }}$ & $\begin{array}{l}\text { Sept. } \\
12\end{array}$ & $\begin{array}{l}\text { Sept. } \\
26\end{array}$ & $\begin{array}{l}\text { Oct. } \\
10\end{array}$ \\
\hline \multirow{5}{*}{ A } & Reducing & $\begin{array}{l}\mathbf{N}^{1} \\
\mathbf{F}^{1}\end{array}$ & $\begin{array}{l}5.39 \\
3.98\end{array}$ & $\begin{array}{l}5.60 \\
4.51\end{array}$ & $\begin{array}{l}5.62 \\
4.42\end{array}$ & $\begin{array}{l}5.67 \\
4.84\end{array}$ & $\begin{array}{l}5.55 \\
4.70\end{array}$ & $\begin{array}{l}5.89 \\
4.20\end{array}$ & $\begin{array}{l}5.74 \\
4.66\end{array}$ & $\begin{array}{l}5.78 \\
4.48\end{array}$ & $\begin{array}{l}6.02 \\
4.23\end{array}$ \\
\hline & Sucrose & $\mathrm{N}$ & 2.78 & 2.80 & 2.90 & $\begin{array}{l}3.04 \\
3.37\end{array}$ & 3.11 & 2.74 & $\begin{array}{l}2.72 \\
2.72\end{array}$ & $\begin{array}{l}.4 .40 \\
2.53\end{array}$ & 2.67 \\
\hline & & $\mathrm{F}$ & 3.08 & 2.74 & 2.71 & 2.78 & 2.84 & 2.48 & 2.68 & 2.35 & 2.70 \\
\hline & Total & $\mathrm{N}$ & 8.17 & & 8.52 & & 8.66 & & 8. & 1 & 8.69 \\
\hline & & $\mathrm{F}$ & 7.06 & 7.25 & 7.13 & 7.62 & 7.54 & 6.68 & 7.34 & 6.83 & 6.93 \\
\hline \multirow{5}{*}{ B } & Reducing & $\mathrm{N}$ & 4.95 & 5.43 & 5.79 & & & & & & \\
\hline & & $\mathrm{F}$ & & & & & & & & & . \\
\hline & $\mathbf{S t}$ & $\begin{array}{l}\mathrm{N} \\
\mathrm{F}\end{array}$ & 3.28 & 3. & 2.96 & $\cdots_{2}^{2}$ & & & 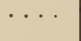 & $\cdots$ & \\
\hline & Total & $\mathrm{N}$ & 8.23 & 8.61 & 8.75 & $\ldots^{2}$ & & & & & $\ldots$ \\
\hline & & $\mathrm{F}$ & 7.78 & 8.09 & 8.98 & $\cdots$ & & & & & \\
\hline \multirow{4}{*}{ C } & Reducing & $\mathbf{N}$ & 4.49 & 5.21 & 5.79 & 5.69 & 5.74 & 5.87 & 5.66 & 6.07 & 6.12 \\
\hline & Sucrose. & $\mathrm{N}$ & 2.67 & 2.81 & 2.56 & 2.90 & 3.00 & 3.31 & 1.64 & 2.55 & 2.46 \\
\hline & Total. & $\mathrm{N}$ & 7.66 & 8.02 & 8.35 & 8.59 & 8.74 & 9.18 & 7.30 & 8.62 & 8.58 \\
\hline & & & & & & & & & & & $\cdots$ \\
\hline \multirow{6}{*}{ D } & Reducing & $\mathrm{N}$ & 4.4 & 4.4 & 4.98 & 4.50 & 5.14 & 5.14 & 5.32 & 5.14 & 5.04 \\
\hline & & $\mathrm{F}$ & $3 . \subseteq$ & 4. & 4.4 & 4.27 & 4.51 & 4.4 & 4. & 0 & 3.98 \\
\hline & Sucrose & $\mathrm{N}$ & 2.4 & 2. & 2.98 & 2.91 & 2.64 & 2.52 & 2. & 2.80 & 2.31 \\
\hline & & $\mathrm{F}$ & 2.3 & 2. & 2.24 & 2.54 & 2.30 & 2.45 & 2. & 2.42 & 2.27 \\
\hline & Tota & N & 6.8 & 7.09 & 7.96 & 7.41 & 7.78 & 7.66 & 7.59 & 7.94 & 7.35 \\
\hline & & $\mathbf{F}$ & 6.32 & 6.40 & 6.66 & 6.81 & 6.81 & 6.92 & 6.66 & 6.52 & 6.25 \\
\hline \multirow{6}{*}{$\mathbf{E}$} & Reducing & $\mathrm{N}$ & 5.47 & 5.2 & 5.6 & 5.93 & 5.70 & 5.44 & 5. & 5.4 & 5.60 \\
\hline & & $\mathbf{F}$ & 4.6 & 5. & 5.26 & 5.31 & 5.30 & 5.0 & & 4 & 4.60 \\
\hline & Sucrose & $\mathrm{N}$ & 2.92 & 2. & 2.67 & 2.52 & 2.91 & 5 & 2. & 2.56 & 1.97 \\
\hline & & 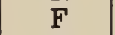 & 2.72 & 2.5 & 2.77 & 2.42 & 2.72 & 2.72 & 2. & 2.47 & 2.01 \\
\hline & Total & $\mathbf{N}$ & 8.3 & 7. & 8.30 & 8.45 & 8.61 & 8.29 & 8. & 8.01 & 7.57 \\
\hline & & $\mathbf{F}$ & 7.4 & 7.71 & 8.03 & 7.73 & 8.02 & 7.73 & 7.62 & 7.39 & 6.61 \\
\hline \multirow{6}{*}{$\mathrm{F}$} & Reducing & N & 4.9 & 4.6 & 5.00 & 5.17 & 5.1 & $5.1^{\prime}$ & 4.97 & 4.9 & 5.25 \\
\hline & & I & 4. & & 4 & 2 & 4.62 & 4. & 5. & $4.3^{3}+x$ & 4.26 \\
\hline & Sucrose & $\mathbf{N}$ & 2.77 & 3.3 & 3.18 & 3.09 & 3.25 & 3.1 & 2. & 3.0 & 2.50 \\
\hline & & $F$ & 2.7 & 3.1 & 3.07 & 2.9 & 2.67 & 2.9 & 3.0 & 3.12 & 1.82 \\
\hline & Total & $\mathrm{N}$ & 7.7 & 8. & 8.18 & 8.26 & 8.36 & 8.29 & 7.71 & 7.96 & 7.75 \\
\hline & & $\mathrm{F}$ & 7.2 & 7.4 & 7.18 & 7.48 & 7.29 & 7.89 & 8.06 & 7.48 & 6.08 \\
\hline \multirow{3}{*}{ G } & Reducing & $\mathbf{N}$ & 4.46 & 5.08 & 4.89 & 5.41 & 5.02 & 5.06 & 5.31 & 5.23 & 5.40 \\
\hline & Sucrose & $\mathrm{N}$ & 2.56 & 1.96 & 2.46 & 2.49 & 2.82 & 2.90 & 2.48 & 2.57 & 2.58 \\
\hline & Total & $\mathrm{N}$ & 7.02 & 7.04 & 7.35 & 7.90 & 7.84 & 7.96 & 7.79 & 7.80 & 7.98 \\
\hline \multirow{5}{*}{$\mathrm{H}$} & & & & & & & & & • & 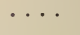 & $\cdots$ \\
\hline & Reducing & $\mathrm{N}$ & 4.62 & 4.86 & 4.90 & 5.39 & 5.31 & 5.58 & 5.14 & 5.08 & 5.48 \\
\hline & Sucrose & $\mathrm{N}$ & 2.62 & 2.47 & 2.64 & 2.50 & 2.56 & 2.79 & 2.53 & 2.70 & 2.30 \\
\hline & Total. & $\mathbf{N}$ & 7.24 & 7.33 & 7.54 & 7.89 & 7.87 & 8.37 & 7.67 & 7.78 & 7.78 \\
\hline & & & & & & & & & & & \\
\hline
\end{tabular}

${ }_{1} \mathbf{N}=$ No segments frozen at center of fruit; $\mathbf{F}=$ one or more segments frozen at center of fruit. In either case, however, the fruits may or may not have been frozen in one or both ends.

2 Plot picked by mistake.

3 Not enough frozen fruit to insure significant results. 

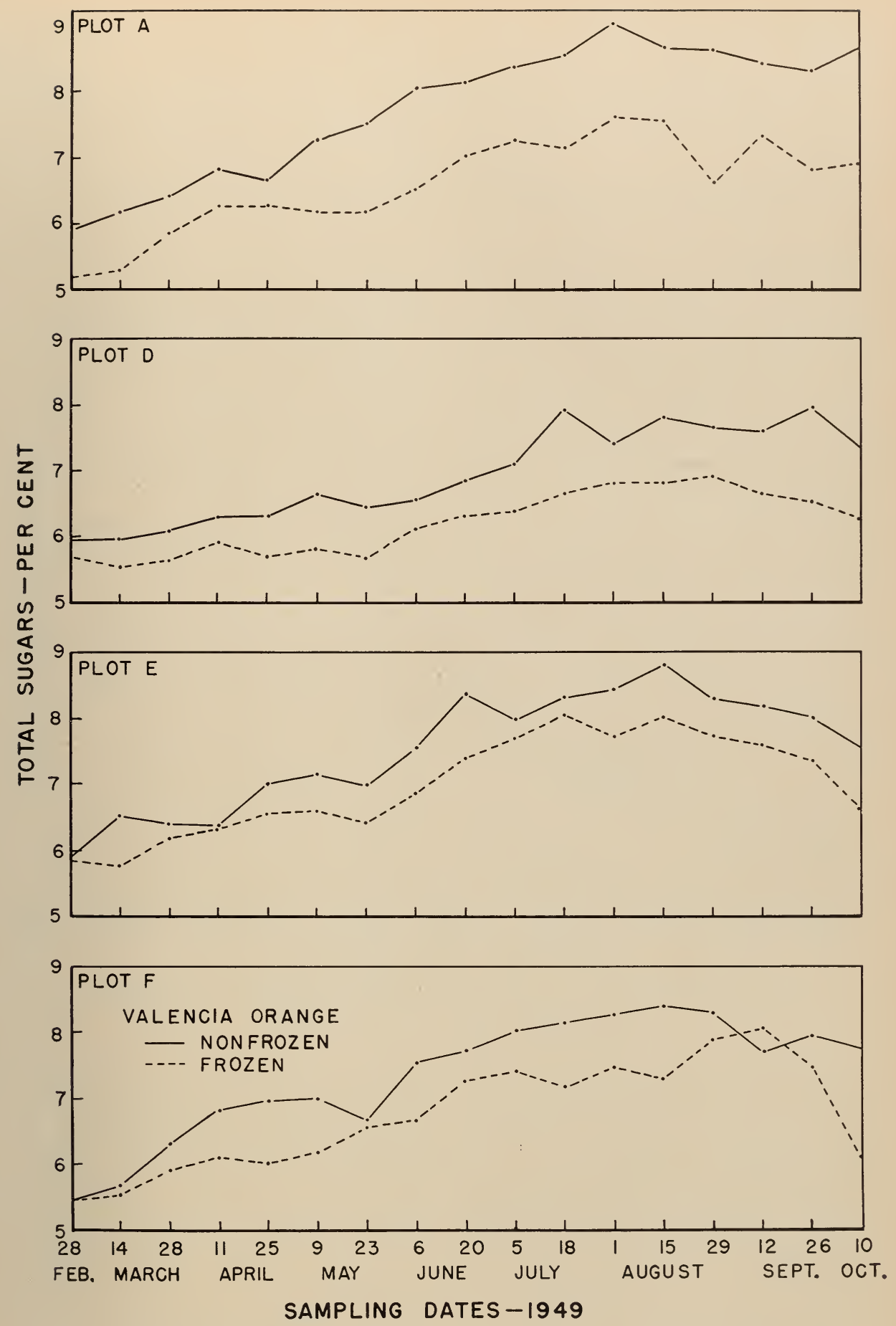

Fig. 15.-Total sugars in juice from nonfrozen and frozen Valencia oranges.

(See table 9 for these and other values.) 

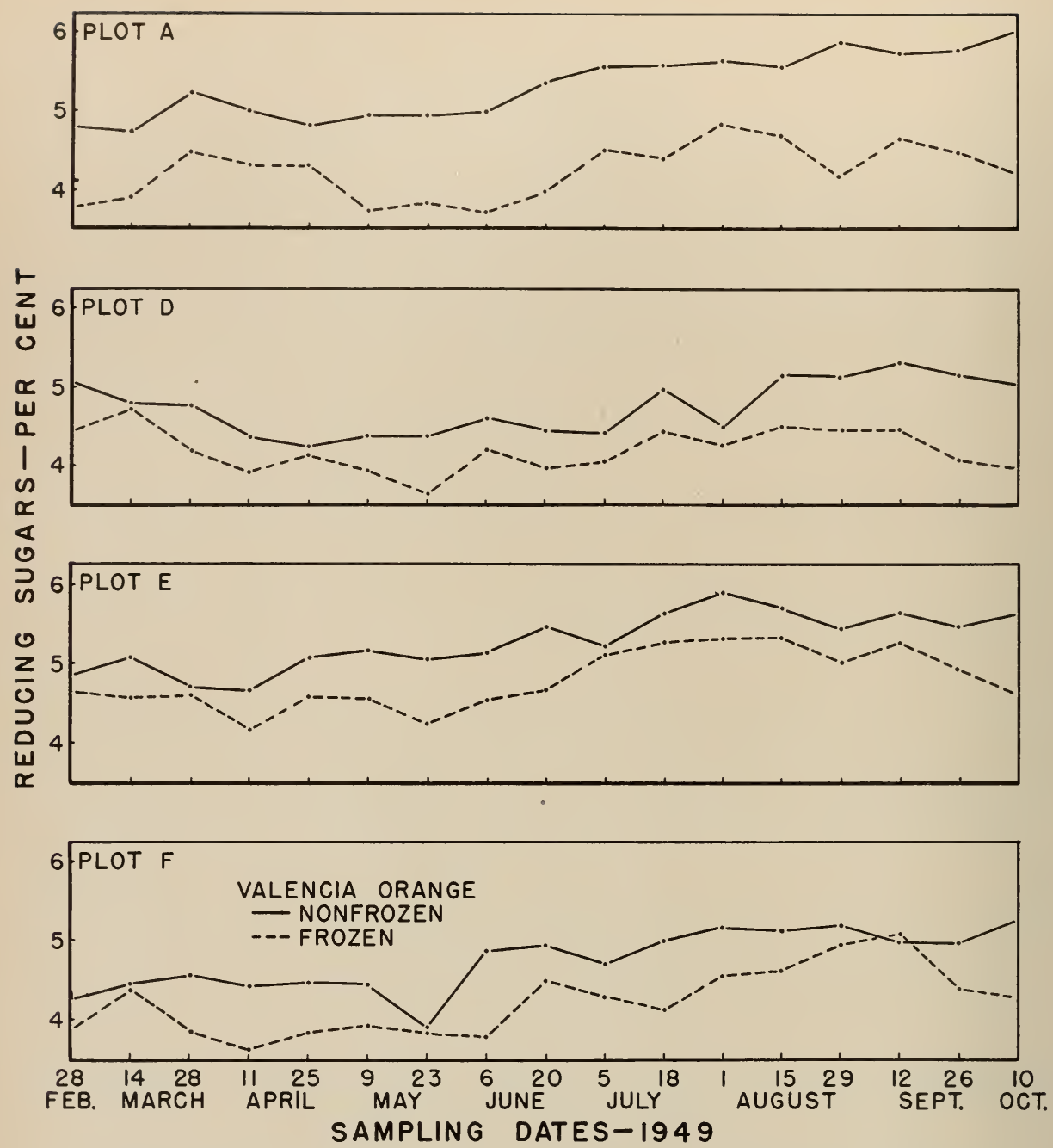

Fig. 16.-Reducing sugars in juice from nonfrozen and frozen Valencia oranges.

(See table 9 for these and other values.)

they increased in size and maturity. The irregular fluctuations which often occurred from test to test are attributed to soil and climatic conditions.

Early estimates and final packout results-Valencia plots. - As already stated, estimates were made on the total amount of freeze injury in the fruits soon after they had been exposed to the freezing temperatures. The data in Table 10 show how accurate these estimates were. They also show how near two groups of inspectors came to agreeing on their estimates of freeze injury in the fruits at the end of the test period. The determinations on February 2 and October 13 were made in the field by packinghouse and field inspectors; those on October 10 were made in the laboratory by the authors. With the exception of Plots C and D, the injury values showed a downward trend in proportion to the estimated injury on February 2 . The values found by the authors on October 10 are a little lower in each in- 
stance than those found by the inspectors on October 13, but the two groups of values are surprisingly close. The one exception is for Plot $\mathrm{D}$, but even this difference is no greater than some of those found by the authors in making successive determinations on fruit samples from different plots as the season advanced (table 1, p. 11).

In so far as the packout grades are concerned (table 10), most of them agree very well with the first percentage estimates of freeze injury on February 2. There were two exceptions. Judging by the results from the other plots, it appears that the estimated amount of freeze injury in Plot C was too high, and in Plot D, too low.

It is well known that, in general, the small fruits on a tree are more likely to be frozen than the large fruits. This is shown indirectly in Table 10 . The fruits from Plots A, D, and E were of poor quality as a result of freeze injury. They were also somewhat smaller than the fruits from the other plots, as shown below:

PORTION OF FRUITS THAT WERE SIZE 200 (23/4" DIAM.) OR LARGER:

$\begin{array}{lccccccc}\text { Plot: } & \text { A } & \text { C } & \text { D } & \text { E } & \text { F } & \text { G } & \text { H } \\ \text { Per cent: } & 22 & 28 & 25 & 24 & 38 & 49 & 32\end{array}$

The average weight of frozen fruits from all plots was slightly less than that of nonfrozen ones, but since average sized fruits, instead of all sizes, were used in these tests, it is probable that the differences in weight were caused by injury and drying in the frozen fruits rather than by differences in size. This is borne out by the fact that the frozen fruits contained less juice than the nonfrozen (tables 5 and 6, pp. 20 and 22).

\begin{tabular}{|c|c|c|c|c|c|c|c|c|}
\hline TABLE & \multicolumn{2}{|c|}{ 10-Freeze Injur } & $\begin{array}{r}\text { Detern } \\
\text { from } \\
\text { ALL FIGUR }\end{array}$ & $\begin{array}{l}\text { inations } \\
\text { the Plots } \\
\text { ES ARE PEF }\end{array}$ & $\begin{array}{l}\text { and Pc } \\
\text { CENT }\end{array}$ & kout Gr & ades of & Fruit \\
\hline \multirow[b]{2}{*}{ Plot } & \multicolumn{3}{|c|}{ Freeze injury ${ }^{2}$} & \multicolumn{5}{|c|}{ Portion of fruit in each grade } \\
\hline & $\underset{2}{\text { February }}$ & $\begin{array}{c}\text { October } \\
10\end{array}$ & $\begin{array}{c}\text { October } \\
13\end{array}$ & Sunkist & Choice & $\begin{array}{l}\text { Orchard } \\
\text { run }\end{array}$ & $\begin{array}{c}\text { Juice fruit } \\
\text { (frozen } \\
\text { and small } \\
\text { sizes) }\end{array}$ & $\begin{array}{l}\text { No of } \\
\text { packed } \\
\text { boxes }\end{array}$ \\
\hline A........ & 60 & 29 & 33 & . & . & 61 & 38 & 62 \\
\hline C... & 51 & 7 & 12 & 68 & 21 & . & 11 & 162 \\
\hline D... & 35 & 27 & 45 & . & . & 74 & 26 & 89 \\
\hline $\mathbf{E}$. & 60 & 32 & 36 & . & . & 85 & 14 & 115 \\
\hline F. & 20 & 17 & 20 & 70 & 18 & . & 10 & 106 \\
\hline G. & . & 4 & 9 & 65 & 25 & . & 8 & 91 \\
\hline H. & 18 & 3 & 12 & 63 & 19 & $\ldots$ & 17 & 91 \\
\hline $\begin{array}{l}1 \text { The valu } \\
\text { periods and th } \\
2 \text { The free } \\
\text { house and fiel } \\
\text { purpose. }\end{array}$ & $\begin{array}{l}\text { ues for Plot } \\
\text { de fruit was } \\
\text { eze injury de } \\
\text { ld inspectors }\end{array}$ & $\begin{array}{l}3 \text { are not } \\
\text { ot graded } \\
\text { erminatic } \\
\text { those o }\end{array}$ & $\begin{array}{l}\text { ven since } \\
\text { on Februa } \\
\text { ctober } 10\end{array}$ & $\begin{array}{l}\text { e plot was } \\
2 \text { and Oc } \\
\text { ere made }\end{array}$ & $\begin{array}{l}\text { icked b } \\
\text { ber } 13 \text { y } \\
\text { n sampl }\end{array}$ & $\begin{array}{l}\text { mistake b } \\
\text { re made i } \\
\text { brought }\end{array}$ & $\begin{array}{l}\text { fore the end } \\
\text { the field by } t \\
\text { the laborat }\end{array}$ & $\begin{array}{l}\text { of the te } \\
\text { he packin } \\
\text { ory for th }\end{array}$ \\
\hline
\end{tabular}




\section{STORAGE TESTS}

Fruits for the storage tests were taken from three blocks of 50 trees each, adjacent to the plots of 25 trees each in three of the eight Valencia groves already mentioned. For the first storage test (March 9-April 7), 15 medium-sized fruits were taken from each tree-750 fruits from each block of 50 trees. Each lot of 750 fruits was thoroughly mixed and then subdivided into five lots of 150 fruits. The subsequent treatment and testing of the fruits from block 1 will be described in detail. The fruits from the other two blocks were treated and tested in the same manner and at the same time.

One of the lots of 150 fruits was divided into two groups of 75 fruits. One was tested for juice quantity and quality and the other for severity of freeze injury. The first tests were made on the day after the fruit was picked. The remaining four lots of 150 fruits each were put into a cold room at a constant temperature of $38^{\circ} \mathrm{F}$ and a relative humidity of 83 per cent. At the end of one week, lot 2 was removed from the cold room and tested in the same way as lot 1 . At the end of two weeks, lots 3,4 , and 5 were removed from the cold room. Lot 3 was tested at once in the usual manner. Lots 4 and 5 were placed in the open in a very large room under conditions that more or less resembled those in a retail store. These two lots were tested at the end of one and two weeks, respectively. The minimum and maximum temperatures in the large room over the 2-week period (March 24 to April 7) ranged from $68^{\circ}$ to $78^{\circ} \mathrm{F}$. The relative humidities over the same periods ranged from 30 to 74 per cent, but stayed between 40 and 50 per cent most of the time.

The second storage test (May 3 to June 2) was conducted in the same manner as the first, except that 1,000 instead of 750 fruits were picked from each of the three blocks of 50 trees. This permitted the use of 100 instead of 75 fruits for each weekly juice and freeze injury determination. The temperature $\left(38^{\circ} \mathrm{F}\right)$ and relative humidity (83 per cent) in the cold room were the same as during the first storage test. In the large room, the temperatures ranged from $72^{\circ}$ to $84^{\circ} \mathrm{F}$. For two days during the first week, the temperature averaged about $81^{\circ} \mathrm{F}$, but during the remainder of the two weeks, the range was from $75^{\circ}$ to $78^{\circ} \mathrm{F}$. The extremes of relative humidity were 20 to 38 per cent. On one day during the first week, the relative humidity dipped from 30 to 20 per cent and back again over a 10-hour period. On the following day it dipped to 22 per cent over a 7 -hour period. During the remainder of the two weeks it ranged, with no sharp breaks, between 32 and 38 per cent.

Others who have made storage tests on frozen oranges have found that there was a decrease in volume of juice, a very slow rise, or none at all, in specific gravity, and a decrease in acids. In general, in these tests the responses of the fruits to the effects of the different temperatures and humidities in the cold room and ir: the large, well-aerated room (table 11) were not so clear-cut, but they were more or less masked by the natural differences. that one would expect to find in the various fruit samples. Though less in quantity, the juice in the fruits that showed freeze injury at the center cut responded to the environmental conditions in much the same manner as did that in the fruits showing no injury at the center cut. For example, in the first storage test, the fruits from Plot D showed a general increase in soluble solids and a decrease in free acids from the first to the last (fifth) test, in both nonfrozen and frozen fruits. In the same storage test, the fruits from Plot F showed no clear-cut increase in soluble solids but did show a decrease in free acids. Both nonfrozen 
TABLE 11 -Quality and Quantity of Juice from Nonfrozen and Frozen Valencia Oranges Kept Under Special Storage Conditions

\begin{tabular}{|c|c|c|c|c|c|c|c|c|c|}
\hline \multirow{4}{*}{ Plot } & \multirow{4}{*}{$\begin{array}{c}\text { Test } \\
\text { no. }\end{array}$} & \multicolumn{8}{|c|}{ First storage test-March 9 to April 7, 1949} \\
\hline & & \multirow{3}{*}{$\begin{array}{c}\text { Fruits, } \\
\text { nonfrozen }(\mathbf{N}) \\
\text { and } \\
\text { frozen }(\mathbf{F})^{1} \\
\text { (per cent) }\end{array}$} & \multicolumn{7}{|c|}{ Juice } \\
\hline & & & \multirow{2}{*}{$\begin{array}{c}\text { Soluble } \\
\text { solids } \\
\text { (per cent) }\end{array}$} & \multirow{2}{*}{$\begin{array}{c}\text { Acids } \\
\text { (as citric) } \\
\text { (per cent) }\end{array}$} & \multicolumn{3}{|c|}{ Sugars (per cent) } & \multirow{2}{*}{$\begin{array}{l}\text { Per fruit } \\
\text { (ml.) }\end{array}$} & \multirow{2}{*}{$\begin{array}{c}\text { Per cent } \\
\text { weight } \\
\text { of fruit }\end{array}$} \\
\hline & & & & & Reducing & Sucrose & Total & & \\
\hline \multirow{10}{*}{ D } & & $\mathrm{N}$ & 9.51 & 1.95 & 4.17 & 2.20 & 6.37 & 41 & 46 \\
\hline & 1 & F $33(52)$ & 9.23 & 1.95 & 4.06 & 1.75 & 5.81 & 33 & 36 \\
\hline & & $\mathrm{N}$ & 9.57 & 1.95 & 4.82 & 1.92 & 6.74 & 46 & 45 \\
\hline & 2 & F $41(43)$ & 9.17 & 1.82 & 3.76 & 1.89 & 5.65 & 35 & 38 \\
\hline & & $\mathbf{N}$ & 9.77 & 1.94 & 4.71 & 1.56 & 6.27 & 43 & 45 \\
\hline & 3 & F $40(57)$ & 9.51 & 1.81 & 4.12 & 2.03 & 6.15 & 40 & 42 \\
\hline & & $\mathrm{N}$ & 10.11 & 1.86 & 4.89 & 1.14 & 6.03 & 43 & 47 \\
\hline & 4 & F $32(45)$ & 9.71 & 1.71 & 4.38 & 1.75 & 6.13 & 33 & 38 \\
\hline & & $\mathrm{N}$ & 10.23 & 1.87 & 5.99 & 0.90 & 6.89 & 42 & 47 \\
\hline & 5 & F $36(64)$ & 9.97 & 1.81 & 4.58 & 2.19 & 6.77 & 35 & 41 \\
\hline \multirow{10}{*}{$\mathbf{E}$} & & $\mathrm{N}$ & 9.57 & 2.10 & 4.09 & 1.93 & 6.02 & 38 & 44 \\
\hline & 1 & F 20 & 9.37 & 1.94 & 3.84 & 1.95 & 5.79 & 31 & 42 \\
\hline & & $\mathbf{N}$ & 9.83 & 2.15 & 4.47 & 1.65 & 6.12 & 36 & 38 \\
\hline & 2 & F $23(44)$ & 9.23 & 1.95 & 4.24 & 1.72 & 5.96 & 32 & 41 \\
\hline & & $\mathrm{N}$ & 9.91 & 2.00 & 4.85 & 1.70 & 6.55 & 38 & 46 \\
\hline & 3 & F 36 & 9.91 & 1.96 & 4.99 & 1.40 & 6.39 & 34 & 43 \\
\hline & & $\mathrm{N}$ & 10.17 & 2.12 & 5.14 & 1.41 & 6.55 & 37 & 45 \\
\hline & 4 & F 25 (39) & 9.91 & 2.05 & 4.98 & 1.41 & 6.39 & 27 & 35 \\
\hline & & $\mathbf{N}$ & 10.43 & 2.00 & 5.15 & 1.63 & 6.78 & 40 & 48 \\
\hline & 5 & F $23(28)$ & 9.91 & 1.76 & 4.66 & 1.84 & 6.50 & 29 & 37 \\
\hline \multirow{10}{*}{$\mathbf{F}$} & & $\mathrm{N}$ & 9.91 & 1.82 & 4.22 & 2.08 & 6.30 & 46 & 49 \\
\hline & 1 & F $20(47)$ & 8.63 & 1.59 & 3.08 & 2.32 & 5.40 & 30 & 35 \\
\hline & & $\mathrm{N}$ & 9.91 & 1.87 & 4.68 & 1.84 & 6.52 & 46 & 46 \\
\hline & 2 & F 15 & 9.83 & 1.79 & 4.18 & 1.76 & 5.94 & 36 & 43 \\
\hline & & $\mathrm{N}$ & 9.31 & 1.77 & 4.44 & 1.73 & 6.17 & 47 & 48 \\
\hline & 3 & F 9 (28) & 9.57 & 1.64 & 4.11 & 1.98 & 6.09 & 39 & 44 \\
\hline & & $\mathrm{N}$ & 9.91 & 1.74 & 4.48 & 2.07 & 6.55 & 46 & 51 \\
\hline & 4 & F $16(25)$ & 9.63 & 1.61 & 4.23 & 2.13 & 6.36 & 40 & 47 \\
\hline & & $\mathbf{N}$ & 10.23 & 1.61 & 4.48 & 2.30 & 6.78 & 46 & 52 \\
\hline & 5 & F 19 (25) & 9.51 & 1.52 & 4.02 & 2.36 & 6.38 & 40 & 42 \\
\hline
\end{tabular}

1 The first value given represents the percentage of fruits in the first lot that showed freeze injury in the center of the fruit only; the tests were made on the juice from these fruits. The values given in parentheses represent the total percentage of fruits in the companion lot that were found to be frozen in other parts as well as in the center; thus the values represent the number of fruits frozen but not severity of injury.

Table 11 continued on next page. 
TABLE 11 (Continued)-Quality and Quantity of Juice from Nonfrozen and Frozen Valencia Oranges Kept Under Special Storage Conditions

\begin{tabular}{|c|c|c|c|c|c|c|c|c|c|}
\hline \multirow{4}{*}{ Plot } & \multirow{4}{*}{$\begin{array}{c}\text { Test } \\
\text { no. }\end{array}$} & \multicolumn{8}{|c|}{ Second storage test-May 3 to June 2, 1949} \\
\hline & & \multirow{3}{*}{$\begin{array}{c}\text { Fruits, } \\
\text { nonfrozen }(\mathbf{N}) \\
\text { and } \\
\text { frozen }(\mathbf{F})^{1} \\
(\text { per cent) }\end{array}$} & \multicolumn{7}{|c|}{ Juice } \\
\hline & & & \multirow{2}{*}{$\begin{array}{c}\text { Soluble } \\
\text { solids } \\
\text { (per cent) }\end{array}$} & \multirow{2}{*}{$\begin{array}{c}\text { Acids } \\
\text { (as citric) } \\
\text { (per cent) }\end{array}$} & \multicolumn{3}{|c|}{ Sugars (per cent) } & \multirow{2}{*}{$\begin{array}{l}\text { Per fruit } \\
\text { (ml.) }\end{array}$} & \multirow{2}{*}{$\begin{array}{c}\text { Per cent } \\
\text { weight } \\
\text { of fruit }\end{array}$} \\
\hline & & & & & Reducing & Sucrose & Total & & \\
\hline \multirow{10}{*}{$\mathbf{D}$} & & $\mathbf{N}$ & 9.91 & 1.33 & 4.38 & 2.34 & 6.72 & 56 & 48 \\
\hline & 1 & F $25(34)$ & 8.31 & 1.26 & 3.35 & 2.19 & 5.54 & 34 & 37 \\
\hline & & $\mathbf{N}$ & 9.23 & 1.30 & 3.96 & 2.06 & 6.02 & 49 & 45 \\
\hline & 2 & F $34(45)$ & 9.23 & 1.28 & 4.08 & 1.83 & 5.91 & 42 & 41 \\
\hline & & $\mathrm{N}$ & 9.91 & 1.31 & 4.12 & 2.59 & 6.71 & 56 & 49 \\
\hline & 3 & F 25 (41) & 9.23 & 1.20 & 3.37 & 2.83 & 6.20 & 43 & 35 \\
\hline & & $\mathbf{N}$ & 9.91 & 1.32 & 4.67 & 2.09 & 6.76 & 54 & 50 \\
\hline & 4 & F 26 (42) & 9.23 & 1.19 & 4.12 & 2.41 & 6.53 & 44 & 43 \\
\hline & & & 9.91 & 1.27 & 5.11 & 1.19 & 6.30 & 52 & 50 \\
\hline & 5 & F $32(44)$ & 9.91 & 1.32 & 4.74 & 1.95 & 6.69 & 43 & 44 \\
\hline \multirow{10}{*}{$\mathbf{E}$} & & $N$ & 10.51 & 1.51 & 5.27 & 1.85 & 7.12 & 42 & 44 \\
\hline & 1 & F 18 (34) & 9.71 & 1.41 & 4.59 & 1.89 & 6.48 & 28 & 40 \\
\hline & & $\mathbf{N}$ & 10.57 & 1.63 & 4.31 & 3.19 & 7.50 & 42 & 47 \\
\hline & 2 & F $16(20)$ & 9.82 & 1.46 & 4.62 & 1.96 & 6.58 & 33 & 36 \\
\hline & & $\mathrm{N}$ & 10.23 & 1.60 & 4.27 & 2.60 & 6.87 & 42 & 46 \\
\hline & 3 & F 9 (24) & 10.23 & 1.56 & 3.91 & 3.00 & 6.91 & 33 & 33 \\
\hline & & $N$ & 10.57 & 1.53 & 5.18 & 1.86 & 7.04 & 45 & 48 \\
\hline & 4 & F 25(37) & 9.91 & 1.31 & 4.57 & 2.09 & 6.66 & 35 & 40 \\
\hline & & $\mathbf{N}$ & 10.83 & 1.49 & 5.84 & 1.70 & 7.54 & 44 & 50 \\
\hline & 5 & F $30(33)$ & 10.57 & 1.35 & 5.33 & 1.87 & 7.20 & 34 & 42 \\
\hline \multirow{10}{*}{$\mathbf{F}$} & & $\mathbf{N}$ & 10.57 & 1.32 & 4.87 & 2.38 & 7.25 & 56 & 52 \\
\hline & 1 & F $14(21)$ & 10.03 & 1.31 & 4.79 & 2.18 & 6.97 & 42 & 44 \\
\hline & & $\mathbf{N}$ & 10.71 & 1.33 & 3.84 & 3.48 & 7.32 & 57 & 52 \\
\hline & 2 & F $18(30)$ & 10.03 & 1.27 & 3.95 & 3.08 & 7.03 & 48 & 41 \\
\hline & & $\mathbf{N}$ & 10.57 & 1.38 & 4.13 & 3.24 & 7.37 & 54 & 55 \\
\hline & 3 & F $15(20)$ & 9.82 & 1.28 & 4.05 & 2.88 & 6.93 & 44 & 43 \\
\hline & & $\mathrm{N}$ & 10.71 & 1.31 & 4.76 & 2.72 & 7.48 & 58 & 54 \\
\hline & 4 & F 13 (19) & 9.71 & 1.27 & 3.83 & 2.58 & 6.41 & 29 & 47 \\
\hline & & $\mathbf{N}$ & 10.97 & 1.30 & 5.27 & 2.33 & 7.60 & 55 & 55 \\
\hline & 5 & F 14 (18) & 9.91 & 1.19 & 4.41 & 2.25 & 6.66 & 43 & 44 \\
\hline
\end{tabular}

1 The first value given represents the percentage of fruits in the first lot that showed freeze injury in the center of the fruit only; the tests were made on the juice from these fruits. The values given in parentheses represent the total percentage of fruits in the companion lot that were found to be frozen in other parts as well as in the center; thus the values represent the number of fruits frozen but not severity of injury. 
and frozen fruits also showed a general increase in total sugars and in per cent of juice per fruit. Table 11 shows other, similar variations for all plots for both storage tests. Water- or X-ray-separated samples of fruit containing small, moderate, or large amounts of freeze injury (see following section) would, no doubt, have shown more marked differences as a result of the storage treatment. It is also possible that greater differences would have occurred had the fruits been kept in the large, well-aerated room for more than two weeks. Two weeks should have been long enough, however, since there is usually less time than that between the removal of the fruit from the refrigerator car and its sale to the public. Nevertheless, these results are of interest because they show the effect of the storage conditions on fruit direct from the grove.

The minimum and maximum percentages of fruits frozen, in the five samples for each plot, for both storage tests, were as follows:

\begin{tabular}{|c|c|c|c|c|}
\hline \multirow[b]{2}{*}{ Plot } & \multicolumn{2}{|c|}{$\begin{array}{l}\text { First storage test } \\
\text { (March 9-April 7) }\end{array}$} & \multicolumn{2}{|c|}{$\begin{array}{l}\text { Second storage test } \\
\text { (May 3-June 2) }\end{array}$} \\
\hline & $\begin{array}{c}\text { Min. } \\
\text { percent }\end{array}$ & $\begin{array}{l}\text { Max. } \\
\text { percent }\end{array}$ & $\begin{array}{c}\text { Min. } \\
\text { percent }\end{array}$ & $\begin{array}{l}\text { Max. } \\
\text { percent }\end{array}$ \\
\hline D & 43 & 64 & 34 & 45 \\
\hline E & 28 & 45 & 20 & 37 \\
\hline$F$ & 25 & 47 & 18 & 30 \\
\hline
\end{tabular}

Although the percentages of fruits frozen were fairly high, the severity of freeze injury was not so great as these percentages might indicate. Only 12 per cent of the 5,250 fruits used in the two tests had three or more frozen segments in one or more portions of the fruit.

In so far as these tests were concerned, there was no indication that the freeze injury was more pronounced after the samples had remained for two weeks in the large, aerated room than it was when they were removed from the cold room. In only one instance was the greatest percentage of frozen fruits found in the fifth, or last, sample. On the other hand, the minimum percentage of frozen fruits was found in three sections of the fifth sample (see table 11, E-5 (18) and F-5 (24) in first storage test, and F-5 (18) in second storage test). The fifth sample included those fruits that had been in the large, aerated room for two weeks after being taken from the cold room.

At the end of the first storage test there were no decayed fruits in any of the 24 storage samples. In the second storage test, eight fruits (out of 2,400 ) decayedfour with molds and four with Alternaria rot. The fruit was picked with clippers, but it was not washed, sterilized, or waxed before being stored.

\section{SEPARATOR TESTS}

Between August 24 and September 22, 1949, determinations were made on the relative quantities and qualities of juice from freshly picked Valencia fruits that had been separated into different lots according to the severity of their freeze injury (table 12 and fig. 17). Separations were made by a new X-ray grader or separator $^{3}$ that was being tested in one of the packinghouses (lots 1-9); by the often-used water separator (lots 10-18); and by hand, at the grading belt (lots 19$24)$. In the first two methods, the fruits were divided into three lots: slightly $(S)$, moderately (M), and badly (B) frozen. The fruits picked by hand from the grading belt were divided into only two lots, those slightly injured and those badly injured, as nearly as could be judged by appearance and feel. Each of the 24 lots contained 150 fruits, except lots 7 to 10 , which had 170 fruits each.

The specific gravity of the fruits was determined in all but six of the 24 lots, thus making it possible to figure the aver-

\footnotetext{
${ }^{3}$ Developed and manufactured by the $\mathrm{Au}$ tomatic X-ray Corporation of Los Angeles, California.
} 
TABLE 12 -Characteristics of Juice from Valencia Oranges that Had Been Divided Into Different Lots According to Severity of Freeze Injury (The Separations Were Made by Three Different Methods)

\begin{tabular}{|c|c|c|c|c|c|c|c|c|c|c|}
\hline \multirow{3}{*}{$\begin{array}{l}\text { Lot } \\
\text { no. }\end{array}$} & \multicolumn{2}{|c|}{ Fruit } & \multicolumn{8}{|c|}{ Juice } \\
\hline & \multirow[b]{2}{*}{$\begin{array}{l}\text { Extent } \\
\text { of freeze } \\
\text { injury }\end{array}$} & \multirow[b]{2}{*}{$\begin{array}{c}\text { Average } \\
\text { specific } \\
\text { gravity }\end{array}$} & \multicolumn{4}{|c|}{ Portion of fruit } & \multirow{2}{*}{$\begin{array}{c}\text { Acids } \\
\text { (as } \\
\text { citric) } \\
\text { (per } \\
\text { cent) }\end{array}$} & \multicolumn{3}{|c|}{ Sugars (per cent) } \\
\hline & & & $\begin{array}{c}\text { Per } \\
\text { fruit } \\
\text { (ml.) }\end{array}$ & $\begin{array}{c}\text { By } \\
\text { weight } \\
\text { (per } \\
\text { cent) }\end{array}$ & $\begin{array}{c}\text { By } \\
\text { volume } \\
\text { (per } \\
\text { cent) }\end{array}$ & $\begin{array}{c}\text { Soluble } \\
\text { solids } \\
\text { (per } \\
\text { cent) }\end{array}$ & & $\begin{array}{c}\text { Reduc- } \\
\text { ing }\end{array}$ & Sucrose & Total \\
\hline
\end{tabular}

By an automatic $\mathrm{X}$-ray separator

\begin{tabular}{|c|c|c|c|c|c|c|c|c|c|c|}
\hline 1 & little. & 0.91 & 73 & 54 & 48 & 11.23 & 1.12 & 5.35 & 2.51 & 7.86 \\
\hline 2 & medium & 0.89 & 65 & 49 & 45 & 10.83 & 1.19 & 5.37 & 2.32 & 7.61 \\
\hline 3 & much. & 0.82 & 45 & 36 & 32 & 9.91 & 1.15 & 4.73 & 1.75 & 6.48 \\
\hline 4 & little. & 0.91 & 70 & 52 & 47 & 11.23 & 1.12 & 5.14 & 2.72 & 7.86 \\
\hline 5 & medium & 0.89 & 64 & 50 & 44 & 11.03 & 1.15 & 5.18 & 2.32 & 7.50 \\
\hline 6 & much. . & 0.82 & 41 & 36 & 31 & 9.83 & 1.17 & 4.89 & 1.73 & 6.62 \\
\hline 7 & little. & & 79 & 57 & . & 11.77 & 1.14 & 5.07 & 3.21 & 8.28 \\
\hline 8 & medium & & 67 & 52 & & 10.57 & 1.17 & 4.52 & 2.90 & 7.42 \\
\hline 9 & much. & & 59 & 48 & . & 10.37 & 1.16 & 4.65 & 2.43 & 7.08 \\
\hline
\end{tabular}

By a water separator

\begin{tabular}{|c|c|c|c|c|c|c|c|c|c|c|}
\hline 10 & little. & . & 66 & 54 & . & 10.31 & 1.19 & 5.01 & 2.19 & 7.20 \\
\hline 11 & medium & $\ldots$ & 54 & 46 & . & 9.57 & 1.21 & 4.42 & 2.13 & 6.55 \\
\hline 12 & much. & & 35 & 40 & . & 9.71 & 1.28 & 4.49 & 1.84 & 6.33 \\
\hline 13 & little. & 93 & 70 & 56 & 51 & 12.23 & 1.08 & 6.13 & 2.41 & 8.54 \\
\hline 14 & medium & 89 & 55 & 52 & 45 & 12.51 & 1.19 & 5.93 & 2.76 & 8.69 \\
\hline 15 & much. & 81 & 38 & 39 & 31 & 12.51 & 1.31 & 5.90 & 2.39 & 8.29 \\
\hline 16 & little. & 94 & 67 & 56 & 52 & 11.31 & 1.08 & 5.27 & 2.67 & 7.94 \\
\hline 17 & medium & 92 & 52 & 54 & 45 & 11.96 & 1.07 & 5.38 & 2.90 & 8.28 \\
\hline 18 & much. & 86 & 32 & 38 & 33 & 11.03 & 1.08 & 4.87 & 2.42 & 7.29 \\
\hline
\end{tabular}

By hand, at grading belt

\begin{tabular}{|c|c|c|c|c|c|c|c|c|c|c|}
\hline 19 & little & 94 & 78 & 58 & 53 & 11.23 & 1.08 & 5.35 & 2.58 & 7.93 \\
\hline 20 & much & 93 & 70 & 55 & 51 & 10.17 & 1.10 & 4.98 & 2.13 & 7.11 \\
\hline 21 & little. & 90 & 66 & 52 & 46 & 10.63 & 1.08 & 5.33 & 2.15 & 7.48 \\
\hline 22 & much & 88 & 59 & 46 & 40 & 9.71 & 1.02 & 4.50 & 2.20 & 6.70 \\
\hline 23 & little. & 90 & 69 & 52 & 45 & 12.17 & 1.34 & 6.10 & 2.35 & 8.45 \\
\hline 24 & much & 88 & 66 & 49 & 44 & 10.57 & 1.22 & 4.95 & 2.21 & 7.16 \\
\hline
\end{tabular}




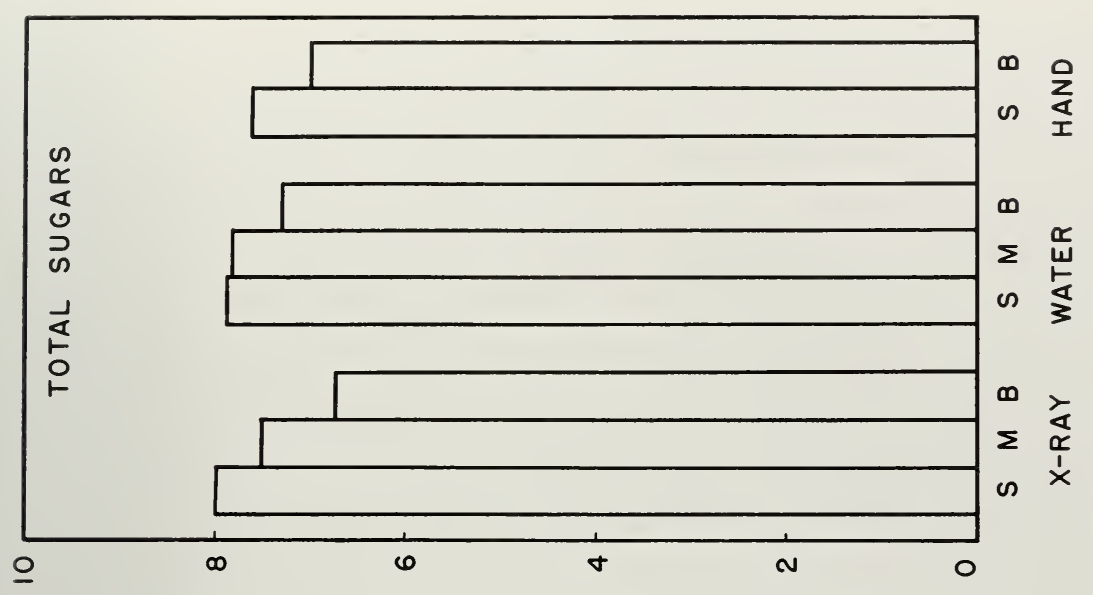



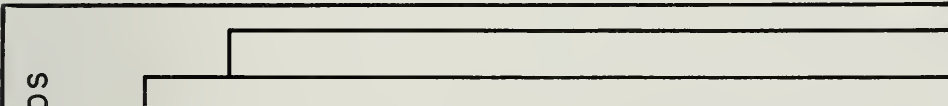



⿰ \

ㄷํ요

$\infty \approx \quad \frac{0}{\underline{0}} \frac{0}{0}$

$\Sigma \stackrel{\frac{\pi}{4}}{\square}$

능 흥

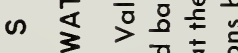



ᄂ

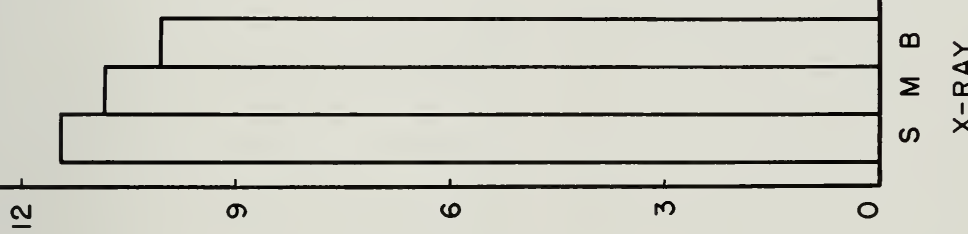

\& $\widehat{\underline{U}}$

르층

पㅎํ웡

表完远 ठํํㄹ

$5 \cong$

ㄷํㅇํำ

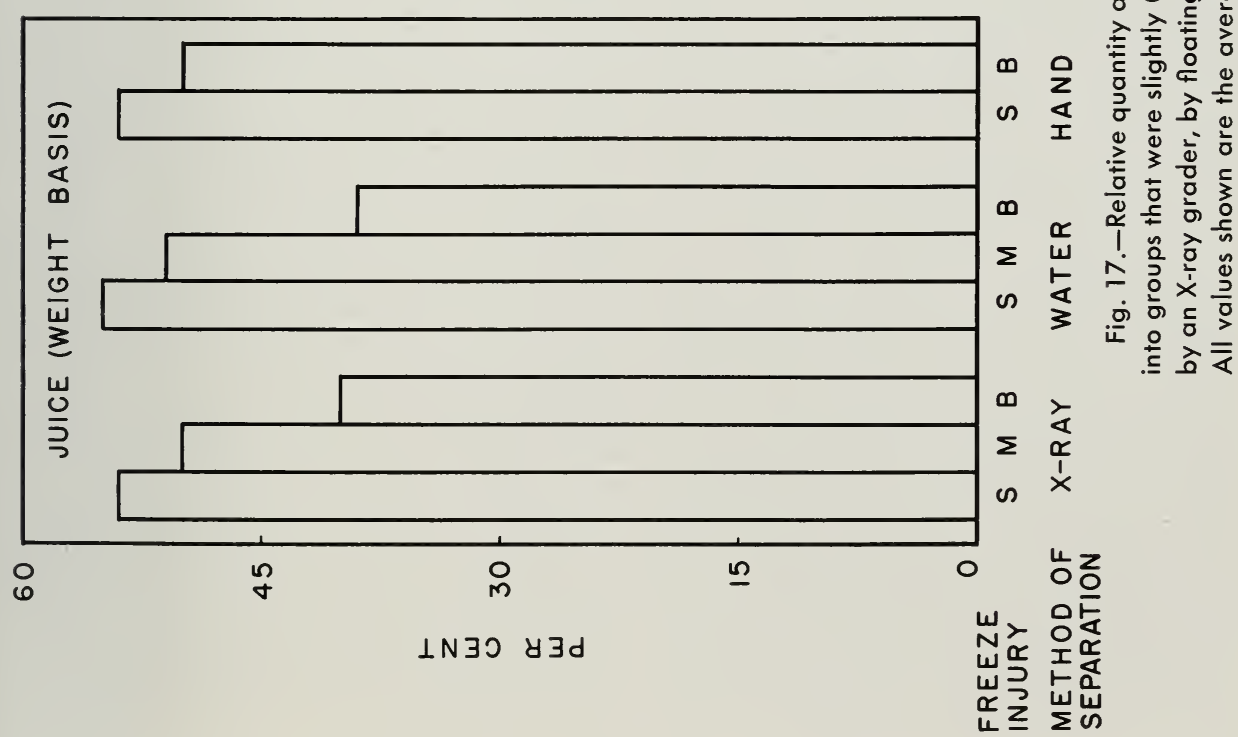


age percentage of juice per fruit on a volume basis (table 12). Since the percentage of juice on a volume basis was not determined for all lots of fruits, the percentage on a weight basis only is shown in Figure 17.

The percentages of juice in the fruits, on both a weight and volume basis, show similar trends, but the values on a volume basis are lower than those on a weight basis. This is not surprising since the specific gravity of the juice is much greater than that of the peel. The specific gravity of the peel alone was not determined, but the specific gravity of the whole fruits used in these tests ranged from only 0.82 to 0.94 (table 12 ), while that of the juice alone ranged from 1.0432 to 1.0505 .

The results presented in Table 12 and Figure 17 show that the X-ray and water separators were at least fairly successful in separating the nonfrozen and frozen fruits. Hand segregation at the grading belt appeared to be less accurate for both separation of nonfrozen and frozen fruits and indication of differences in percentages of juice. It should be pointed out, however, that differences in the soluble solids and total sugars were smaller in the water-separated than in the hand-separated fruits. This was probably because the natural variability in specific gravity and concentration of soluble solids in the different lots of fruit tended to nullify the differences caused by freeze injury. The fruit samples for the two methods came from widely separated areas.

Some fruits that were supposedly nonfrozen were found to be frozen, in both the water-and X-ray-separated lots, while others, that were supposedly frozen, were found to be nonfrozen. Such results are to be expected because of the relatively great differences in specific gravity of healthy fruits. Chace and Church (1927) found that oranges of high specific gravity can be dried 20 per cent or more and still have a higher specific gravity than other healthy fruits that have not been dried. A cull or frozen fruit, therefore, may have a higher specific gravity than a first-grade nonfrozen fruit.

Granulation.-Granulation is an abnormality which often appears in Valencia fruits in California, especially toward the end of the picking season. The juice sacs (vesicles), primarily in the stem end of the fruit, become enlarged, relatively hard, and light gray in color. In most years of freezing temperatures, granulation and freeze injury may be found in the same fruits. This fact apparently has caused many people, in the past, to form the general conclusion that freezing temperatures are the cause of granulation. Evidence has been presented which shows that this conclusion is wrong (Bartholomew, Sinclair, and Young, 1936; Bartholomew and Sinclair, 1938; Bartholomew, Sinclair, and Turrell, 1941; and Bain, 1949). Probably the reason for this division of opinion is that granulation has been confused with other abnormalities, such as "dry juice sac" and even freeze injury itself. At any rate, it appears to be quite generally conceded that there was very much less granulation during the summer and fall of 1949 than there had been for many years previously, in spite of the very low freezing temperatures of the preceding winter (1948-49). Of the 9,750 fruits, from the eight plots, that were cut and examined in the laboratory to determine the presence or absence of granulation and the total percentage of freeze injury, only two showed fully developed, granulated vesicles. Only a few others showed early or intermediate stages of granulation. At the close of the season, when the remaining fruits from the plots were picked and inspected in the packinghouse, the reports on the prevalence of granulation were: 3 plots, none; 1 plot, mostly slight; 2 plots, mostly very slight; and 1 plot, very slight. (One plot, B, was picked before the end of the season.) 


\section{RESULTS-MARSH GRAPEFRUIT}

The tests on Marsh grapefruit were limited in comparison with those made on Valencias. The fruits were obtained from two plots of 50 trees each, in two groves near Riverside. Four tests, at 3 -week intervals, were made on the fruit samples from one plot, and three similar tests on samples from the other plot. Four "outside" and four "inside," mediumsized fruits were picked from each tree on each date, making two samples of 200 fruits each. The outside fruits $(\mathrm{O})$ were those plainly exposed on the surface of the tree; inside fruits (I) came from the interior where they were hidden by the relatively dense foliage. The inside fruits, therefore, were partially protected from the low temperatures because of reduced radiation. The fruits in each sample were thoroughly mixed and then divided into two lots of 100 each-one for analysis, the other for freeze injury determinations.

The values represented in Figure 18 are the average of all of those shown in Table 13 for Plots A and B, respectively. The values used in constructing the histograms (fig. 18) for "total freeze injury" appear in parentheses in the table and represent total freeze injury, rather than that found at the center only.

The average volume of juice per fruit (ml.) was always less in the frozen than in the nonfrozen fruits (table 13). These differences may be partially explained on the basis of the relative sizes of the frozen and nonfrozen, outside fruits, but do not apply to the inside fruits from Plot A. The average weight of the outside, frozen fruits $(8.4 \mathrm{oz}$.) was less than that of the nonfrozen fruits $(9.2$ oz.). On the other hand, the average weight of the inside, frozen fruits $(10.1 \mathrm{oz}$.) was a little greater than that of the nonfrozen fruits (9.8 oz.). For Plot B, the weights of the frozen fruits from both outside and inside were less than those of the nonfrozen. They were: outside frozen, $8.5 \mathrm{oz} .$, nonfrozen, $9.0 \mathrm{oz}$; inside frozen, $7.9 \mathrm{oz}$., nonfrozen, $8.9 \mathrm{oz}$.

It is evident, from Figure 18, that the total freeze injury was less in Plot A than in Plot B, and that the difference between the amounts of frozen outside and inside fruit was greater for Plot A than for Plot B. The inside fruits always had a lower concentration of total soluble solids and total sugars than did the outside ones. This is of interest because the outside fruits were more severely frozen than the inside ones. It is well known, however, that inside fruits normally have lower concentrations of soluble solids than do outside fruits. Apparently, the differences in severity of freeze injuries were not great enough to counteract this normal condition.

Although the concentrations of soluble solids and sugars were higher in the outside than in the inside fruits, there was little difference between the concentrations of these substances in the nonfrozen and frozen fruits. This inconsistency is, no doubt, partly due to the fact that the center cut alone, which was made on the fruits from which the juice was reamed, did not give accurate information as to the location and severity of freeze injury in the fruits. This assumption is substantiated by the following data:

$\begin{array}{lcc}\begin{array}{l}\text { DISTRIBUTION OF INJURY IN FROZEN } \\ \text { GRAPEFRUIT }\end{array} & \text { Fruits } & \text { Segments } \\ & \text { per cent } & \text { per cent } \\ \text { Frozen in stem end } & 32.4 & 40.0 \\ \text { Frozen in center } & 39.4 & 35.2 \\ \text { Frozen in stylar end } & 28.2 & 24.8\end{array}$

These results show that while the greatest percentage of fruits were frozen in the center, that portion contained only 35.2 per cent of the frozen segments while the stem end contained a significantly greater percentage of frozen segments than did either the center or the stylar end. Of all 







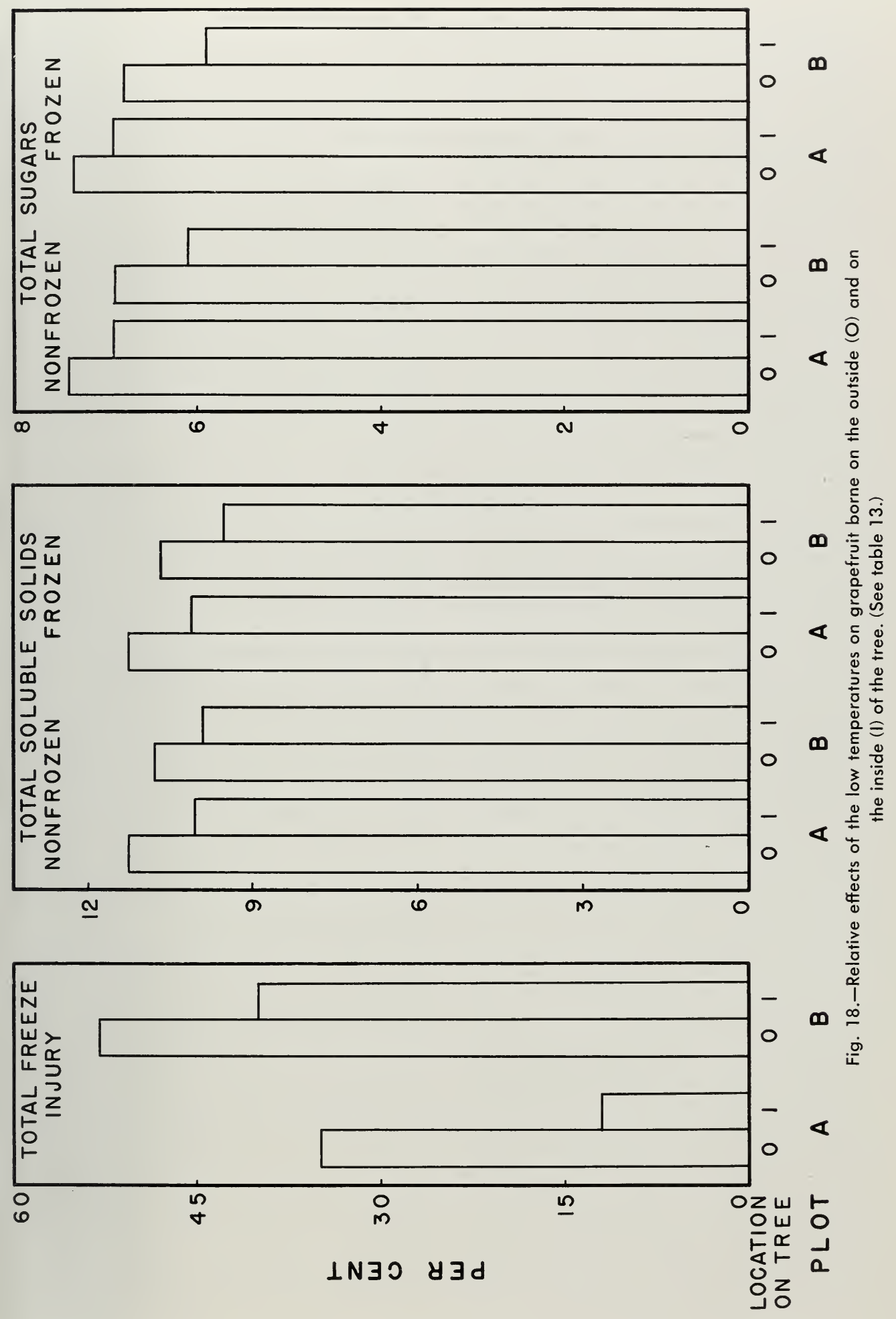


fruits frozen in the stem end, 63.3 per cent were outside and 36.7 per cent inside ones. Outside fruits frozen in the center totaled 70.4 per cent; inside ones, 29.6 per cent.

As already mentioned, the grapefruit tests were limited since only two groves were concerned. However, the relative percentages of frozen segments in the different portions of the fruit are probably significant, because the trends of these results are the same as those for the much more extensive tests made on Valencia fruits.

There were no constant and consistent differences in the percentages of free acids in the nonfrozen and frozen and in the outside and inside fruits. With one exception, the acids were highest in both outside and inside frozen fruits from Plot A. In Plot B, the acids were highest in two thirds of the frozen outside fruits, and lowest in two thirds of the frozen inside fruits.

Although the period covered by these tests was not very long, the frozen grapefruits, like the Valencias, showed a tendency to fill in the shrunken spaces by the growth and enlargement of the adjoining and other nonfrozen segments. In so far as these grapefruit tests were concerned, the freeze injury caused a reduction in quantity of juice but the effect on quality was relatively slight.

\section{DISCUSSION}

By far the larger portion of the laboratory studies that were made at this Station following the freeze of January, 1913, was confined to the determinations of the differences in composition between nonfrozen and badly frozen oranges (navels) and lemons (Young, 1915; Bailey and Wilson, 1916; Thomas, Young, and Smith, 1919). On the other hand, the present studies, following the freezes of late December, 1948, and early January, 1949, have been confined largely to the study of the changes which occurred in Valencia oranges and Marsh grapefruit, 50 per cent or less of which had been frozen, many only lightly. In the 1913 tests, the differences were inevitably great, while in the recent tests they were much smaller and more variable. The variability in juice quantity and quality was due to the fact that segregation into nonfrozen and frozen fruits, based on the center cut alone, did not always give accurate information as to the severity of freeze injury in the entire fruit. The results may be better understood, however, by checking the companion lots of fruits that were cut at the ends as well as at the center so that the total percentage of freeze injury could be determined (tables $1,2,3,4$, and 13 ).

In the past, several methods have been suggested for determining the presence and severity of freeze injury in citrus fruits. Some of those methods are: specific gravity (Chace, 1918; Chace and Church, 1927); presence of hesperidin crystals (Denny, 1917) ; electrical resistance of individual segments (Davis, 1935 ) ; relative volumes of juice (Gray, 1935; Beacham, 1941); and relative rates of respiration (Gonzalez, 1948). Only one of these methods is used to any marked extent-specific gravity, the principle upon which the water separator is based. The other two methods most commonly used are: visual observation following transverse cuts through the fruit, and use of the X-ray grader.

Several of the methods mentioned for segregating nonfrozen and frozen fruits are not practical because it takes too long to make the tests and to differentiate chemical and physical changes occurring in frozen fruit, and because of the normal variations in noninjured fruits. Visual observation, following transverse cuts, was the principal method used in these 
tests, but a limited number of observations and determinations were made on water- and X-ray-separated fruits.

Based on the center cut alone, the results show that the nonfrozen fruits always had more juice and usually had a greater concentration of total soluble solids, free acids, and sugars than did the frozen fruits (tables 5 to 9, and figs. 11 to 16). The information that has been obtained from these studies is of much interest and value because it shows what to expect in the development and quality of Valencia oranges and grapefruit that have been partially frozen and then subjected to the climatic and other conditions which prevailed following the freezes.

From the over-all results of the present studies, it appears that a transverse stemend cut as well as a transverse center cut should be made to determine the actual severity of freeze injury in Valencias and grapefruit. A transverse center cut alone may appear to be adequate since 66.7 per cent of the frozen Valencia fruits from all the plots were frozen in the center. Of these fruits, 29.8 per cent were frozen in the center only, 35.8 in center and stem end only, 5.9 in center and stylar end only, and 28.5 in all three portions. Of the 33.3 per cent that were not frozen in the center, 68.6 per cent were frozen in the stem end only, 22.8 in the stylar end only and 8.6 in both stem and stylar ends. These conditions tend to explain why the quantity and quality of the juice from the fruits in which the center cut revealed no freeze injury were higher than those from the fruits which showed injury at the center cut. While these results appear to justify the use of the center cut alone, the data reported in Tables 2, 3, and 4, and Figures 8, 9, and 10 indicate that the center cut alone does not give sufficient information as to the extent and severity of the freeze injury in the fruit. That both center and stem-end cuts should be made is supported by the following:
1. Of the fruits which were frozen in one portion only, 45.4 per cent were frozen in the stem end, 39.5 per cent in the center, and 15.1 per cent in the stylar end (table 2).

2. Of the fruits which were frozen in one or more portions, 40.7 per cent were frozen in the stem end, 39.5 per cent in the center, and 19.8 per cent in the stylar end (table 3 and fig. 8 ).

3. Of the total number of frozen segments in one or more portions of the fruit, 44.6 per cent were in the stem end, 39.5 per cent in the center, and 15.9 per cent in the stylar end (table 4 and fig. 9). In this connection it should be noted that the data in the first half of the table show that in those fruits in which two or less segments were frozen, fewer fruits (35.6 per cent) and fewer segments (35.9 per cent) were frozen in the stem end than in the center (39.3 per cent fruits and 41.3 per cent segments). These were fruits in which the freeze injury was relatively slight. The second half of the table, however, records the results of much more severe freeze injury-three or more frozen segments per fruit. Here, more fruits (45.7 per cent) and many more segments (48.3 per cent) were frozen in the stem end than in the center (40.3 per cent fruits and 38.7 per cent segments).

4. The data for grapefruit are similar to those for the Valencias. Although the number of grapefruit frozen in the stem end (32.4 per cent) was only one third of the total number of fruits frozen, 40.0 per cent of all frozen segments were in the stem end of the fruit.

It is realized that these findings are the results of one freeze year only, but they appear to justify careful consideration in future studies and recommendations, at least in so far as Valencias and grapefruit are concerned.

As already shown in the tables and figures, the juice from nonfrozen fruits (both Valencias and grapefruit) was usually greater in quantity and superior 
in quality to that from frozen fruits. From the data on page 45, it seems logical to conclude that if the segregations into nonfrozen and frozen fruits could have been based on both center and stem-end cuts instead of on the center cut only, the differences in quantity and quality of the juice from the two groups would have been noticeably greater than they were.

On the days following the nights of lowest temperatures, the relative humidities were low (19 and 25 per cent), and on January 6 and 7 the temperatures were fairly high $\left(72^{\circ}\right.$ and $\left.70^{\circ} \mathrm{F}\right)$. Following these dates, both night and day temperatures were relatively low and humidities high. This combination of weather conditions probably explains, or helps to explain, why there was a noticeable recovery of the injured fruits. These weather conditions during the spring and summer apparently favored the retention of a high concentration of acids and prevented the production of a high sugar content in the juice (tables 8 and 9 ).

In the district where the test plots were located, the Valencia oranges are often left on the trees for several months after they have reached commercial maturity (when juice contains 8 parts soluble solids to 1 part acids). So far as is known, no consecutive tests over such a long period of time have been made on Valencias to determine the effects of such a procedure on the quantity and quality of the juice in the fruits. The results of the tests reported here, made every two weeks from February 28 until October 10, 1949, show that, under the conditions which prevailed during that period, fruit which reached commercial maturity about May 1 could be "stored on the trees" until about the middle of August without showing any appreciable reduction in quantity or quality of juice (figs. 11 to 16). At that time, the quality began to decrease but the quantity remained approximately the same or increased until possibly the last test on October 10.

\section{ACKNOWLEDGMENTS}

For coöperation and assistance given during these studies, the authors gladly express the thanks of the University to: Mr. J. A. Prizer, Secretary and Manager of the Placentia Orange Growers Association and member of the Board of Directors of the California Fruit Growers Exchange, who was largely responsible for the initiation of the problem, and who gave generously of his time while the study was in progress; to the California Fruit Growers Exchange for financial aid; to Mr. J. R. MacRill, of the California Fruit Growers Exchange, who made available the rooms for the storage experiments at their Field Service Laboratory, Ontario, California; to Marcelina Arroues; C. M. McColloch; Mrs. Anna Haster; Mrs. F. H. Lyon; L. P. D. Desautels; H. E. Balmer; the National Orange Growers Association; George C. Pooley, in whose groves the test plots were located, and who furnished experimental fruit gratis; and to those who assisted in many other ways.

In order that the information in our publications may be more intelligible, it is sometimes necessary to use trade names of products and equipment rather than complicated descriptive or chemical identifications. In so doing, it is unavoidable in some cases that similar products which are on the market under other trade names may not be cited. No endorsement of named products is intended nor is criticism implied of similar products which are not mentioned. 


\section{LITERATURE CITED}

BaILEY, H. S., and C. P. Wilson

1916. The composition of sound and frozen lemons with special reference to the effect of slow thawing on frozen lemons. Jour. Ind. Eng. Chem. 8:902-04.

Bain, F. M.

1949. Citrus and climate. Calif. Citrogr. 34(9) : 382, 412-14; 34(10) : 426, 448-49.

Bartholomew, E. T., W. B. Sinclair, and F. D. Young 1936. Granulation and frozen Valencia oranges. Calif. Citrogr. $21: 458$.

Bartholomew, E. T., and W. B. Sinclair

1938. Further studies on the relation of low temperatures to granulation. Calif. Citrogr. 23:163, 192.

Bartholomew, E. T., W. B. Sinclair, and F. M. Turrell

1941. Granulation of Valencia oranges. Univ. Calif. Agr. Exp. Sta. Bul. 647.

BEACHAM, L. M.

1941. Studies of Florida and California oranges in regard to the relationship of frost damage to juice content. Jour. Assn. Off. Agr. Chem. 24:788-93.

BLISH, M. J.

1933. Report on diastatic value of flour. Jour. Assn. Off. Agr. Chem. 16:497-504.

1934. Report on diastatic value of flour. Jour. Assn. Off. Agr. Chem. 17:394-99.

Chace, E. M.

1918. Detection and elimination of frosted fruit. Calif. Citrogr. 4:108-09, 144.

Chace, E. M., and C. G. Church

1927. Methods of detecting and measuring frost injury. Fla. St. Hort. Soc. Proc. 40:112-16.

DAVIS, WARD B.

1935. Detection and measurement of freeze injury in Valencia oranges. Amer. Jour. Bot. 22: $559-66$.

DENNy, F. E.

1917. Detection and elimination of frozen oranges. Calif. Citrogr. 2:9.

Gonzalez, Leon G.

1948. Effects of freezing on the respiration rate of oranges and lemons. Amer. Soc. Hort. Sci. Proc. $51: 132-36$.

Gray, W. Y.

1935. The effect of freezing on oranges. Fla. Dept. Agr. Chem. Div. Pp. 17-30.

Thomas, E. E., H. D. Young, and C. O. Smith

1919. Changes that take place in frozen oranges and lemons. Univ. Calif. Agr. Exp. Sta. Bul. 304.

Young, H. D.

1915. The composition of frozen oranges and lemons. Jour. Ind. Eng. Chem. 7:1038-1041. 


\section{TABLE OF CONTENTS}

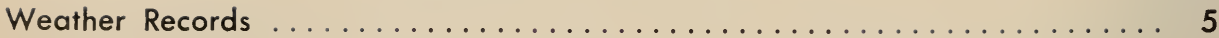

Methods ................................... 6

Results-Valencia Oranges ....................... 7

General observations ............................ 7

Laboratory tests . . . . . . . . . . . . . . . . . . . . . . . . . . . . 10

Total freeze injury in all parts of fruits tested $\ldots \ldots \ldots \ldots \ldots \ldots$

Fruits frozen in one portion only $\ldots \ldots \ldots \ldots \ldots \ldots \ldots \ldots \ldots \ldots \ldots \ldots \ldots$

Fruits frozen in one or more portions . . . . . . . . . . . . 13

Severity of freeze injury ......................... 13

Volume of juice per fruit ........................ 15



Total soluble solids ........................... 21



Sugars . . . . . . . . . . . . . . . . . . . . . 28

Early estimates and final packout results-Valencia plots . . . . . . . . 32

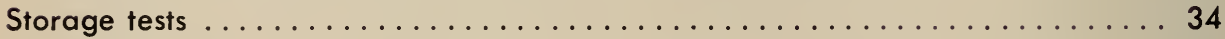

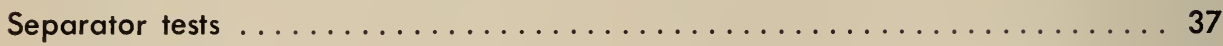

Granulation ................................ 40

Results-Marsh grapefruit $\ldots \ldots \ldots \ldots \ldots \ldots \ldots \ldots \ldots \ldots \ldots \ldots \ldots \ldots \ldots$

Discussion ................................. 44



Literature Cited ............................ 47 